\title{
High variability in dissolved iron concentrations in the vicinity of the Kerguelen Islands (Southern Ocean)
}

\author{
F. Quérouée ${ }^{1,2,3,4}$, G. Sarthou ${ }^{2}$, H. F. Planquette ${ }^{2}$, E. Bucciarelli ${ }^{1,2}$, F. Chever ${ }^{2}$, P. van der Merwe , D. Lannuzel $^{3,4}$,

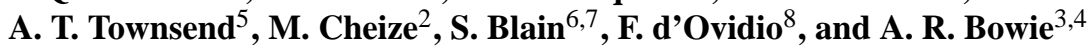 \\ ${ }^{1}$ Université de Bretagne Occidentale, IUEM, 29200 Brest, France \\ ${ }^{2}$ LEMAR-UMR 6539, CNRS-UBO-IRD-IFREMER, Place Nicolas Copernic, 29280 Plouzané, France \\ ${ }^{3}$ Institute for Marine and Antarctic Studies, University of Tasmania, Hobart, TAS 7001, Australia \\ ${ }^{4}$ Antarctic Climate \& Ecosystems Cooperative Research Centre, University of Tasmania, Hobart, TAS 7001, Australia \\ ${ }^{5}$ Central Science Laboratory, University of Tasmania, Hobart, TAS 7001, Australia \\ ${ }^{6}$ Laboratoire Océanographie Biologique de Banyuls sur Mer, Université Pierre et Marie Curie, Paris 06, quai Fontaulé, \\ 66650 Banyuls sur Mer, France \\ ${ }^{7}$ Laboratoire Océanographie Biologique de Banyuls sur Mer, CNRS, Paris 06, quai Fontaulé, 66650 Banyuls sur Mer, France \\ ${ }^{8}$ Sorbonne Universités (UPMC, Univ Paris 06)-CNRS-IRD-MNHN, LOCEAN-IPSL, 4 place Jussieu, 75005 Paris, France
}

Correspondence to: G. Sarthou (geraldine.sarthou@univ-brest.fr)

Received: 28 November 2014 - Published in Biogeosciences Discuss.: 6 January 2015

Revised: 25 April 2015 - Accepted: 12 May 2015 - Published: 25 June 2015

\begin{abstract}
Dissolved $\mathrm{Fe}(\mathrm{dFe})$ concentrations were measured in the upper $1300 \mathrm{~m}$ of the water column in the vicinity of the Kerguelen Islands as part of the second KErguelen Ocean Plateau compared Study (KEOPS2). Concentrations ranged from $0.06 \mathrm{nmol} \mathrm{L}^{-1}$ in offshore, Southern Ocean waters to $3.82 \mathrm{nmol} \mathrm{L}^{-1}$ within Hillsborough Bay, on the north-eastern coast of the Kerguelen Islands. Direct island runoff, glacial melting and resuspended sediments were identified as important inputs of $\mathrm{dFe}$ that could potentially fertilise the northern part of the plateau. A significant deep $\mathrm{dFe}$ enrichment was observed over the plateau with $\mathrm{dFe}$ concentrations increasing up to $1.30 \mathrm{nmol} \mathrm{L}^{-1}$ close to the seafloor, probably due to sediment resuspension and pore water release. Biological uptake was shown to induce a significant decrease in $\mathrm{dFe}$ concentrations between two visits ( 28 days apart) at a station above the plateau. Our work also considered other processes and sources, such as lateral advection of enriched seawater, remineralisation processes, and the influence of the polar front (PF) as a vector for Fe transport. Overall, heterogeneous sources of Fe over and off the Kerguelen Plateau, in addition to strong variability in Fe supply by vertical or horizontal transport, may explain the high variability in $\mathrm{dFe}$ concentrations observed during this study.
\end{abstract}

\section{Introduction}

Iron $(\mathrm{Fe})$ has been shown to be an essential trace metal controlling phytoplankton growth and primary production in about $50 \%$ of the world's oceans (Moore et al., 2001) including high-nutrient, low-chlorophyll (HNLC) regions. The main sources of $\mathrm{Fe}$ in the world's oceans are atmospheric deposition (wet or dry) (e.g. Jickells et al., 2005), sediment resuspension (Lam and Bishop, 2008), pore water release (Elrod et al., 2004), hydrothermal activity (Tagliabue et al., 2010), and remineralisation of organic matter (Ibisanmi et al., 2011). In the Southern Ocean, dust inputs have been considered to be small due to its remoteness from land masses (Wagener et al., 2008; Heimburger et al., 2013), but the other sources of Fe have been shown to induce natural fertilisation in several sites including the Crozet Plateau (Pollard et al., 2009; Planquette et al., 2011), the Scotia Sea (Dulaiova et al., 2009; Ardelan et al., 2010; Nielsdóttir et al., 2012; Hatta et al., 2013; Measures et al., 2013), the Ross Sea (Smith Jr. et al., 2012), and the Kerguelen Plateau (Blain et al., 2007, 2008), all stimulating phytoplankton blooms and enhancing carbon sequestration with varying magnitudes.

During the first KErguelen Ocean Plateau compared Study (KEOPS1), carried out in late austral summer 2005, the im- 
pact of natural fertilisation on primary productivity and carbon export was demonstrated in this area (Blain et al., 2007; Savoye et al., 2008). The surface area of the observed phytoplankton bloom was about $45000 \mathrm{~km}^{2}$ and led to a carbon sequestration efficiency 18 times higher (Chever et al., 2010) than estimated around the Crozet Islands (bloom area $90000 \mathrm{~km}^{2}$ ) during the CROZEX experiment in the same year (Pollard et al., 2009; Morris and Charette, 2013). A second cruise, KEOPS2 (KErguelen Ocean and Plateau compared Study 2), was designed to study the development of the Kerguelen bloom in early spring 2011 and in the offshore fertilisation area further east. In this paper, we present dissolved $\mathrm{Fe}(\mathrm{dFe})$ concentrations clustered into five groups (near-coastal, plateau, recirculation, north of the polar front (PF), HNLC area) and discuss their distributions in relation to potential new and regenerated sources. Where possible, an estimate of the biological uptake of $\mathrm{Fe}$ is provided. Finally, $\mathrm{dFe}$ data presented in this paper together with particulate $\mathrm{Fe}$ data from a closely aligned companion study (van der Merwe et al., 2015) are combined by Bowie et al. (2014) in order to establish short-term Fe budgets at three sites (above the plateau, in the recirculation area, and the HNLC area).

\section{Materials and methods}

\subsection{Study area}

During austral spring (7 October-30 November 2011), 149 seawater samples from 15 stations were collected as part of the KEOPS2 oceanographic research cruise (Fig. 1, Table 1) in the vicinity of the Kerguelen Islands in the Southern Ocean $\left(48.40-50.62^{\circ} \mathrm{S}\right.$ and $\left.66.68-74.65^{\circ} \mathrm{E}\right)$. Two stations were sampled over the plateau (A3 and G-1), south of the island. A3 was visited twice, 28 days apart, in the early stage and during the build-up of the spring phytoplankton bloom. An east-west (E-W) transect (from TEW-1 to F-L) was sampled from the Kerguelen coast to offshore waters, and crossed the PF twice. Finally, three additional stations were analysed within a complex system of recirculation located in a stationary meander of the PF (E-3, E-4W-2 and E-5). An openocean station (R-2) was located in the HNLC area south-west of the Kerguelen Islands and south of the PF.

\subsection{Sampling and analytical methods}

Cleaning, sampling, handling, and processing of the samples were conducted using stringent trace metal clean protocols as recommended by the GEOTRACES programme (Cutter et al., 2010; Cutter, 2013). Samples were collected using a trace metal clean rosette (TMR, model 1018, General Oceanics) equipped with twelve $10 \mathrm{~L}$ externally closing Teflon-lined Niskin-1010X bottles mounted on a polyurethane powdercoated aluminium frame specially designed for trace metal work (Bowie et al., 2009). Seawater was subsampled for $\mathrm{dFe}$ via a Teflon tap connected to acid-cleaned $0.2 \mu \mathrm{m}$ filter cartridges (Pall Acropak ${ }^{\circledR}$ and Sartorius Sartrobran ${ }^{\circledR}$ 300). Acid-cleaned low-density polyethylene bottles $(60 \mathrm{~mL})$ were rinsed three times with $\sim 20 \mathrm{~mL}$ of seawater before final sample collection. Dissolved $\mathrm{Fe}$ samples were acidified to $\mathrm{pH}$ $\sim 2$ using concentrated ultrapure hydrochloric acid (Seastar Baseline, $\mathrm{HCl}$ ). The sample bottles were then double-bagged and stored at ambient temperature in the dark until analysis. The shallowest sample was collected at $15 \mathrm{~m}$ depth in order to avoid contamination from the ship. Samples were collected off plateau to a depth of $1300 \mathrm{~m}$.

Dissolved $\mathrm{Fe}$ was analysed on board at least $24 \mathrm{~h}$ after collection by means of flow injection analysis (FIA) with online solid-phase extraction onto 8-hydroxyquinoline (8-HQ) resin and chemiluminescence detection, following a method adapted from Obata et al. (1993) (Sarthou et al., 2003). All analyses were conducted inside a class 100 laminar flow hood within a containerised clean laboratory, using high-efficiency particulate air (HEPA) filters. During the cruise, hydrogen peroxide, ammonium acetate buffer, and $\mathrm{HCl}$ blanks were consistently below the detection limit $\left(0.017 \pm 0.012 \mathrm{nmol} \mathrm{L}^{-1}, n=22\right)$, and therefore the system was deemed suitable for open-ocean seawater analysis (Johnson et al., 2007). Each sample was analysed in triplicate with an average precision of $4.8 \%(n=149)$. The North Pacific SAFe Surface (SAFe S) $\left(0.094 \pm 0.003 \mathrm{nmol} \mathrm{L}^{-1}, n=3\right)$ and SAFe Deep D2 $\left(0.95 \pm 0.05 \mathrm{nmol} \mathrm{L}^{-1}, n=3\right)$ reference samples were measured for $\mathrm{dFe}$, and the results were in excellent agreement with the consensus values $\left(\mathrm{S} 1=0.095 \pm 0.008 \mathrm{nmol} \mathrm{L}^{-1}\right.$ and $\mathrm{D} 2=0.96 \pm 0.02 \mathrm{nmol} \mathrm{L}^{-1}$; Johnson et al., 2007).

Potential temperature $(\Theta)$, salinity $(S)$, oxygen $\left(\mathrm{O}_{2}\right)$, and beam attenuation data were retrieved from the CTD sensors. We used the data from the CTD casts that were deployed immediately before or after our TMR casts.

\section{Results and discussion}

\subsection{Clustering of stations}

The presentation and discussion of results are organised into clusters, which were defined considering the hydrography and the complex regional circulation. Water masses were identified using $\Theta-S$ diagrams (Fig. 2).

Cluster 1 includes TEW-1 and TEW-2 stations located at the north-eastern flank of the Kerguelen Islands and north of the PF, with shallow waters $(\sim 85 \mathrm{~m}$ bottom depth), low salinity (33.6-33.8), and low density anomaly $\left(<27.0 \mathrm{~kg} \mathrm{~m}^{-3}\right)$. Below the surface mixed layer (SML), the water masses can be defined as subsurface (shelf) waters.

Cluster 2 includes stations located above the central part of the Kerguelen Plateau (A3-1, A3-2, G-1, and TEW-3, bottom depths lower than $600 \mathrm{~m}$ ), and located south of the PF, with a minimum of temperature around $200 \mathrm{~m}$. At A3-1, stratification had not yet started and surface water temperature 
Table 1. Station name, longitude, latitude, sampling date, mixed layer depth (MLD), station bottom depth, location, dissolved iron concentrations ( $\mathrm{dFe}$ ), and standard deviation (SD) during KEOPS2. MLD were estimated using, as a reference, potential densities at both 10 and $20 \mathrm{~m}$. When estimates are different, both values are given.

\begin{tabular}{|c|c|c|c|c|c|c|c|c|}
\hline Station & Long [degrees east] & Lat [degrees south] & Date & $\operatorname{MLD}[\mathrm{m}]$ & Bot. depth [m] & Depth $[\mathrm{m}]$ & $\mathrm{dFe}\left[\mathrm{nmol} \mathrm{L} \mathrm{L}^{-1}\right]$ & $\mathrm{SD}[\mathrm{nmol} \mathrm{L}-1]$ \\
\hline \multirow[t]{4}{*}{ A3-1 } & 72.06 & 50.62 & $20 / 10 / 11$ & $164-165$ & 530 & 45 & 0.28 & 0.00 \\
\hline & & & & & & 105 & 0.40 & 0.01 \\
\hline & & & & & & 160 & 0.32 & 0.02 \\
\hline & & & & & & 340 & 0.53 & 0.03 \\
\hline \multirow[t]{16}{*}{$\mathrm{R}-2$} & 66.68 & 50.38 & $26 / 10 / 11$ & $76-95$ & 2500 & 40 & 0.09 & 0.01 \\
\hline & & & & & & 70 & 0.08 & 0.01 \\
\hline & & & & & & 100 & 0.17 & 0.00 \\
\hline & & & & & & 140 & 0.18 & 0.01 \\
\hline & & & & & & 170 & 0.12 & 0.01 \\
\hline & & & & & & 200 & 0.27 & 0.00 \\
\hline & & & & & & 235 & 0.26 & 0.00 \\
\hline & & & & & & 300 & 0.33 & 0.01 \\
\hline & & & & & & 350 & 0.35 & 0.01 \\
\hline & & & & & & 400 & 0.38 & 0.01 \\
\hline & & & & & & 500 & 0.39 & 0.01 \\
\hline & & & & & & 700 & 0.28 & 0.02 \\
\hline & & & & & & 900 & 0.28 & 0.01 \\
\hline & & & & & & 1000 & 0.31 & 0.02 \\
\hline & & & & & & 1200 & 0.30 & 0.01 \\
\hline & & & & & & 1300 & 0.32 & 0.01 \\
\hline \multirow[t]{4}{*}{ TEW-1 } & 69.83 & 49.13 & $31 / 10 / 11$ & $32-42$ & 86 & 15 & 1.82 & 0.38 \\
\hline & & & & & & 40 & 2.52 & 0.12 \\
\hline & & & & & & 50 & 2.58 & 0.16 \\
\hline & & & & & & 62 & 3.82 & 0.04 \\
\hline \multirow[t]{5}{*}{ TEW-2 } & 70.65 & 48.88 & $31 / 10 / 11$ & $40-70$ & 85 & 15 & 1.26 & 0.03 \\
\hline & & & & & & 30 & 1.61 & 0.02 \\
\hline & & & & & & 40 & 1.70 & 0.14 \\
\hline & & & & & & 50 & 1.80 & 0.07 \\
\hline & & & & & & 62 & 1.82 & 0.01 \\
\hline \multirow[t]{9}{*}{ TEW-3 } & 71.02 & 48.78 & $31 / 10 / 11$ & $16-94$ & 560 & 20 & 0.19 & 0.02 \\
\hline & & & & & & 40 & 0.12 & 0.02 \\
\hline & & & & & & 70 & 0.09 & 0.01 \\
\hline & & & & & & 100 & 0.21 & 0.00 \\
\hline & & & & & & 150 & 0.19 & 0.01 \\
\hline & & & & & & 200 & 0.19 & 0.01 \\
\hline & & & & & & 300 & 0.26 & 0.01 \\
\hline & & & & & & 400 & 0.37 & 0.00 \\
\hline & & & & & & 480 & 0.52 & 0.01 \\
\hline \multirow[t]{12}{*}{ TEW-4 } & 71.62 & 48.62 & $1 / 11 / 11$ & 95 & 1600 & 40 & 0.17 & 0.02 \\
\hline & & & & & & 70 & 0.15 & 0.01 \\
\hline & & & & & & 100 & 0.20 & 0.01 \\
\hline & & & & & & 150 & 0.10 & 0.01 \\
\hline & & & & & & 200 & 0.11 & 0.00 \\
\hline & & & & & & 300 & 0.21 & 0.00 \\
\hline & & & & & & 400 & 0.30 & 0.00 \\
\hline & & & & & & 500 & 0.36 & 0.01 \\
\hline & & & & & & 600 & 0.39 & 0.01 \\
\hline & & & & & & 700 & 0.35 & 0.01 \\
\hline & & & & & & 1000 & 0.40 & 0.00 \\
\hline & & & & & & 1300 & 0.42 & 0.01 \\
\hline \multirow[t]{12}{*}{ E-2 } & 72.07 & 48.52 & $1 / 11 / 11$ & $42-43$ & 2000 & 40 & 0.08 & 0.01 \\
\hline & & & & & & 70 & 0.08 & 0.00 \\
\hline & & & & & & 100 & 0.10 & 0.00 \\
\hline & & & & & & 150 & 0.07 & 0.01 \\
\hline & & & & & & 200 & 0.18 & 0.00 \\
\hline & & & & & & 300 & 0.22 & 0.01 \\
\hline & & & & & & 400 & 0.23 & 0.01 \\
\hline & & & & & & 500 & 0.28 & 0.01 \\
\hline & & & & & & 600 & 0.34 & 0.01 \\
\hline & & & & & & 700 & 0.28 & 0.01 \\
\hline & & & & & & 1000 & 0.37 & 0.01 \\
\hline & & & & & & 1300 & 0.37 & 0.01 \\
\hline TEW-5 & 72.78 & 48.47 & $1 / 11 / 11$ & $22-56$ & 2250 & 40 & 0.12 & 0.01 \\
\hline & & & & & & 70 & 0.13 & 0.01 \\
\hline & & & & & & 100 & 0.16 & 0.01 \\
\hline & & & & & & 150 & 0.16 & 0.02 \\
\hline & & & & & & 200 & 0.21 & 0.08 \\
\hline & & & & & & 300 & 0.30 & 0.01 \\
\hline & & & & & & 400 & 0.39 & 0.01 \\
\hline & & & & & & 500 & 0.36 & 0.01 \\
\hline & & & & & & 600 & 0.31 & 0.01 \\
\hline & & & & & & 700 & 0.34 & 0.01 \\
\hline & & & & & & 1000 & 0.44 & 0.01 \\
\hline & & & & & & 1300 & 0.42 & 0.01 \\
\hline
\end{tabular}


Table 1. Continued.

\begin{tabular}{|c|c|c|c|c|c|c|c|c|}
\hline Station & Long [degrees east] & Lat [degrees south] & Date & $\operatorname{MLD}[\mathrm{m}]$ & Bot. depth [m] & Depth [m] & $\mathrm{dFe}\left[\mathrm{nmol} \mathrm{L}{ }^{-1}\right]$ & $\mathrm{SD}\left[\mathrm{nmol} \mathrm{L}{ }^{-1}\right]$ \\
\hline \multirow[t]{8}{*}{ TEW-7 } & 73.98 & 48.45 & $2 / 11 / 11$ & $22-24$ & 2500 & 20 & 0.39 & 0.02 \\
\hline & & & & & & 40 & 0.22 & 0.02 \\
\hline & & & & & & 150 & 0.40 & 0.04 \\
\hline & & & & & & 200 & 0.46 & 0.02 \\
\hline & & & & & & 300 & 0.46 & 0.02 \\
\hline & & & & & & 400 & 0.48 & 0.02 \\
\hline & & & & & & 1000 & 0.56 & 0.01 \\
\hline & & & & & & 1300 & 0.59 & 0.02 \\
\hline \multirow[t]{12}{*}{ E-3 } & 71.97 & 48.70 & $3 / 11 / 11$ & $32-35$ & 1900 & 20 & 0.38 & 0.03 \\
\hline & & & & & & 40 & 0.31 & 0.02 \\
\hline & & & & & & 70 & 0.22 & 0.01 \\
\hline & & & & & & 100 & 0.24 & 0.01 \\
\hline & & & & & & 130 & 0.24 & 0.02 \\
\hline & & & & & & 200 & 0.33 & 0.01 \\
\hline & & & & & & 300 & 0.50 & 0.01 \\
\hline & & & & & & 400 & 0.46 & 0.01 \\
\hline & & & & & & 600 & 0.50 & 0.02 \\
\hline & & & & & & 800 & 0.50 & 0.02 \\
\hline & & & & & & 1000 & 0.50 & 0.01 \\
\hline & & & & & & 1300 & 0.52 & 0.01 \\
\hline \multirow[t]{11}{*}{ F-L } & 74.65 & 48.52 & $7 / 11 / 11$ & 47 & 2700 & 20 & 0.26 & 0.02 \\
\hline & & & & & & 35 & 0.17 & 0.03 \\
\hline & & & & & & 60 & 0.30 & 0.00 \\
\hline & & & & & & 100 & 0.33 & 0.01 \\
\hline & & & & & & 200 & 0.48 & 0.03 \\
\hline & & & & & & 300 & 0.40 & 0.03 \\
\hline & & & & & & 400 & 0.40 & 0.01 \\
\hline & & & & & & 600 & 0.56 & 0.03 \\
\hline & & & & & & 800 & 0.61 & 0.02 \\
\hline & & & & & & 1000 & 0.67 & 0.03 \\
\hline & & & & & & 1300 & 0.61 & 0.05 \\
\hline \multirow[t]{8}{*}{ A3-2 } & 72.05 & 50.62 & $16 / 11 / 11$ & 123 & 525 & 37 & 0.18 & 0.02 \\
\hline & & & & & & 70 & 0.14 & 0.01 \\
\hline & & & & & & 108 & 0.14 & 0.01 \\
\hline & & & & & & 210 & 0.51 & 0.01 \\
\hline & & & & & & 300 & 0.66 & 0.01 \\
\hline & & & & & & 400 & 0.81 & 0.02 \\
\hline & & & & & & 450 & 1.04 & 0.00 \\
\hline & & & & & & 480 & 1.30 & 0.01 \\
\hline \multirow[t]{12}{*}{ G-1 } & 71.88 & 49.90 & $9 / 11 / 11$ & $60-68$ & 590 & 20 & 0.21 & 0.04 \\
\hline & & & & & & 40 & 0.13 & 0.01 \\
\hline & & & & & & 70 & 0.23 & 0.01 \\
\hline & & & & & & 100 & 0.17 & 0.01 \\
\hline & & & & & & 150 & 0.19 & 0.01 \\
\hline & & & & & & 200 & 0.18 & 0.01 \\
\hline & & & & & & 250 & 0.24 & 0.01 \\
\hline & & & & & & 300 & 0.49 & 0.01 \\
\hline & & & & & & 350 & 0.67 & 0.01 \\
\hline & & & & & & 400 & 0.74 & 0.02 \\
\hline & & & & & & 500 & 0.59 & 0.02 \\
\hline & & & & & & 540 & 0.99 & 0.01 \\
\hline \multirow[t]{12}{*}{ E-4W-2 } & 71.42 & 48.75 & $18 / 11 / 11$ & $26-35$ & 1390 & 20 & 0.20 & 0.01 \\
\hline & & & & & & 40 & 0.16 & 0.01 \\
\hline & & & & & & 70 & 0.15 & 0.01 \\
\hline & & & & & & 100 & 0.11 & 0.00 \\
\hline & & & & & & 150 & 0.22 & 0.01 \\
\hline & & & & & & 180 & 0.28 & 0.00 \\
\hline & & & & & & 230 & 0.28 & 0.01 \\
\hline & & & & & & 300 & 0.35 & 0.01 \\
\hline & & & & & & 500 & 0.41 & 0.01 \\
\hline & & & & & & 700 & 0.42 & 0.01 \\
\hline & & & & & & 900 & 0.40 & 0.00 \\
\hline & & & & & & 1100 & 0.61 & 0.02 \\
\hline \multirow[t]{12}{*}{ E-5 } & 71.88 & 48.40 & $19 / 11 / 11$ & $35-41$ & 1920 & 25 & 0.06 & 0.01 \\
\hline & & & & & & 40 & 0.06 & 0.00 \\
\hline & & & & & & 70 & 0.10 & 0.00 \\
\hline & & & & & & 110 & 0.08 & 0.01 \\
\hline & & & & & & 150 & 0.11 & 0.01 \\
\hline & & & & & & 200 & 0.14 & 0.01 \\
\hline & & & & & & 350 & 0.23 & 0.00 \\
\hline & & & & & & 500 & 0.43 & 0.01 \\
\hline & & & & & & 700 & 0.37 & 0.00 \\
\hline & & & & & & 900 & 0.34 & 0.01 \\
\hline & & & & & & 1100 & 0.40 & 0.00 \\
\hline & & & & & & 1300 & 0.39 & 0.03 \\
\hline
\end{tabular}




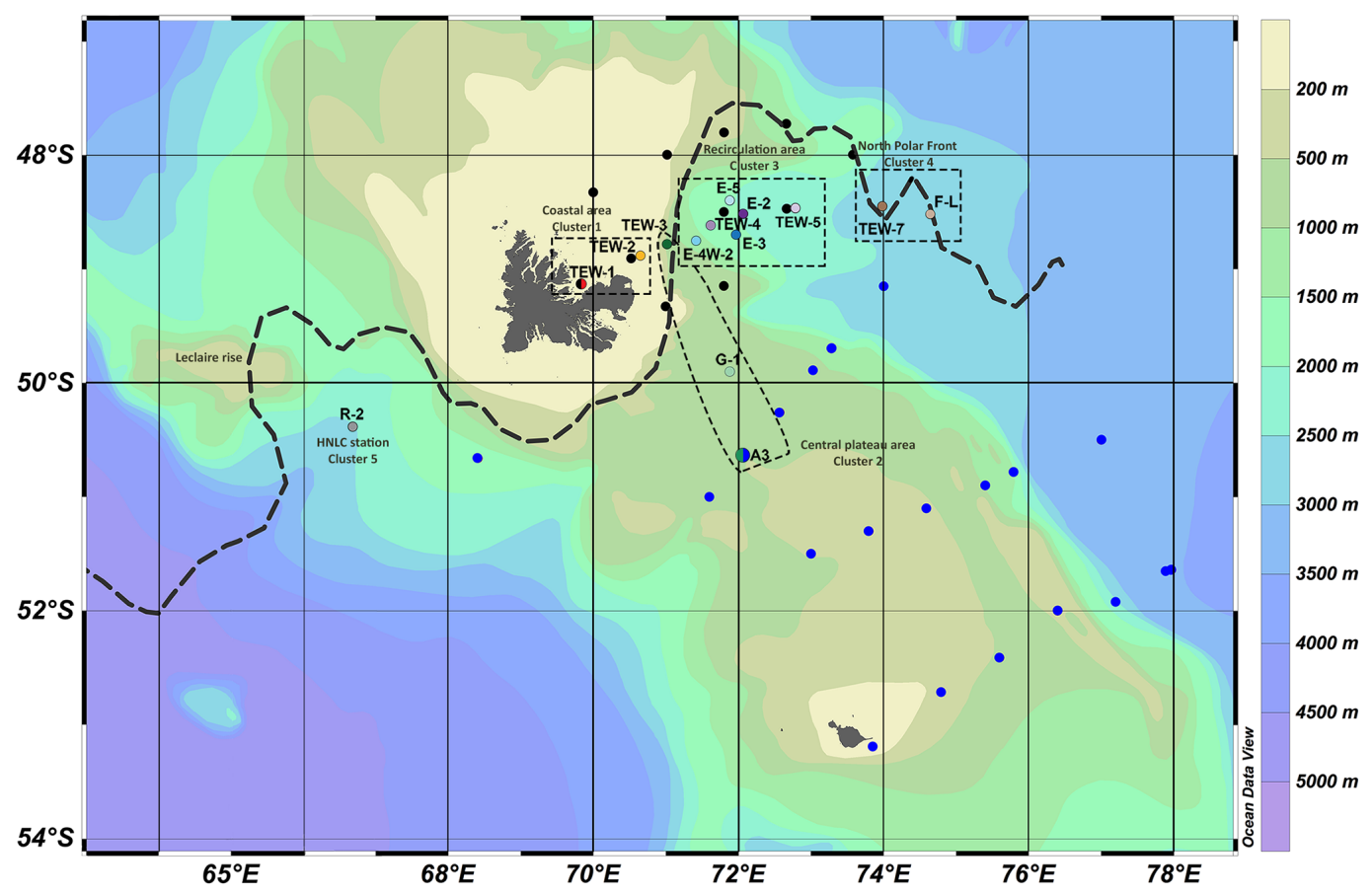

Figure 1. Map showing the bathymetry of the area and the stations visited during KEOPS2 (yellow-orange for cluster 1, green for cluster 2, blue-violet for cluster 3, brown for cluster 4, and grey for cluster 5), KEOPS1 (blue dots; Blain et al., 2008), and ANTARES3 (black dots; Bucciarelli et al., 2001). The dashed line represents the approximate location of the polar front (200 m) (Park et al., 2014).

was low $\left(\sim 1.7^{\circ} \mathrm{C}\right)$ and typical of winter conditions. Stations A3-2 and G-1 presented similar water masses (Fig. 2). The SMLs were observed down to 125 and $65 \mathrm{~m}$, respectively. Below, winter water (WW) is encountered with temperatures around $1.7^{\circ} \mathrm{C}$ at 225 and $115-210 \mathrm{~m}$, respectively. The inclusion of TEW-3 in cluster 2 is debatable given its location at the plateau edge. Indeed, although TEW-3 can be considered as south of the PF, its location within the polar front jet is likely more correct. However, a structure comparable to A31, A3-2, and G-1 was observed below the surface waters with a WW temperature just below $2{ }^{\circ} \mathrm{C}$.

East of the Kerguelen Plateau, the PF presents a permanent meander (Park et al., 2014). This meander delimits a region with a complex circulation including stations TEW-4, E-2, TEW-5, E-3, E-4W-2, and E-5, and is defined as cluster 3. All these stations showed very similar $\Theta-S$ profiles (Fig. 2). The warmest sea-surface temperatures were observed at station E-5, due to the decrease in the mixed layer depth (MLD) and progression into summer. Below the surface water (SW), a subsurface temperature minimum $\left(\sim 1.7-1.8^{\circ} \mathrm{C}\right)$ was observed between 170 and $220 \mathrm{~m}$, characteristic of the WW (Fig. 2). Below, the oxygen minimum around $600-800 \mathrm{~m}$ $\left(175 \mu \mathrm{mol} \mathrm{kg}{ }^{-1}\right)$ can be attributed to the Upper Circumpolar Deep Water (UCDW). Deeper in the water column (below $1300 \mathrm{~m})$, the salinity increased towards a salinity maximum ( 34.75), indicating the presence of the Lower Circumpolar Deep Water (LCDW).
Stations TEW-7 and F-L (cluster 4), located north of the $\mathrm{PF}$ and east of the plateau presented the warmest surface waters of the study $\left(4.2^{\circ} \mathrm{C}\right)$ characteristic of the Subantarctic Surface Water (SASW). The Antarctic Intermediate Water (AAIW) occurred deeper, at 170 (TEW-7) and $290 \mathrm{~m}$ (F-L) (Fig. 2). Below the AAIW, the UCDW and the LCDW were encountered.

Station R-2, located in the HNLC area, stands on its own in cluster 5. A salinity minimum (33.78) and a surface temperature maximum $\left(2.0^{\circ} \mathrm{C}\right)$ were observed in the upper $100 \mathrm{~m}$, which is characteristic of the SW (Fig. 2). At $200 \mathrm{~m}$, the temperature minimum $\left(1.6^{\circ} \mathrm{C}\right)$ was indicative of WW. The oxygen minimum $\left(170 \mu \mathrm{mol} \mathrm{kg}{ }^{-1}\right)$ defined the UCDW. Deeper in the water column (below $1300 \mathrm{~m}$ ), the salinity increased towards a salinity maximum $(\sim 34.73)$ indicating the presence of the LCDW.

\subsection{A general overview of dFe distributions}

Median dFe concentrations for the different water masses and clusters (2 to 5) are plotted in Fig. 3.

In the surface waters, near-coastal stations presented the highest concentrations $\left(2.10 \pm 0.77 \mathrm{nmol} \mathrm{L}^{-1}\right)$. When considering the other stations, the lowest seasurface concentrations were found at station R-2 $\left(0.09 \pm 0.01 \mathrm{nmol} \mathrm{L}^{-1}\right)$, while the highest were observed in cluster $4\left(0.26 \pm 0.09 \mathrm{nmol} \mathrm{L}^{-1}\right)$. If we compare our results 

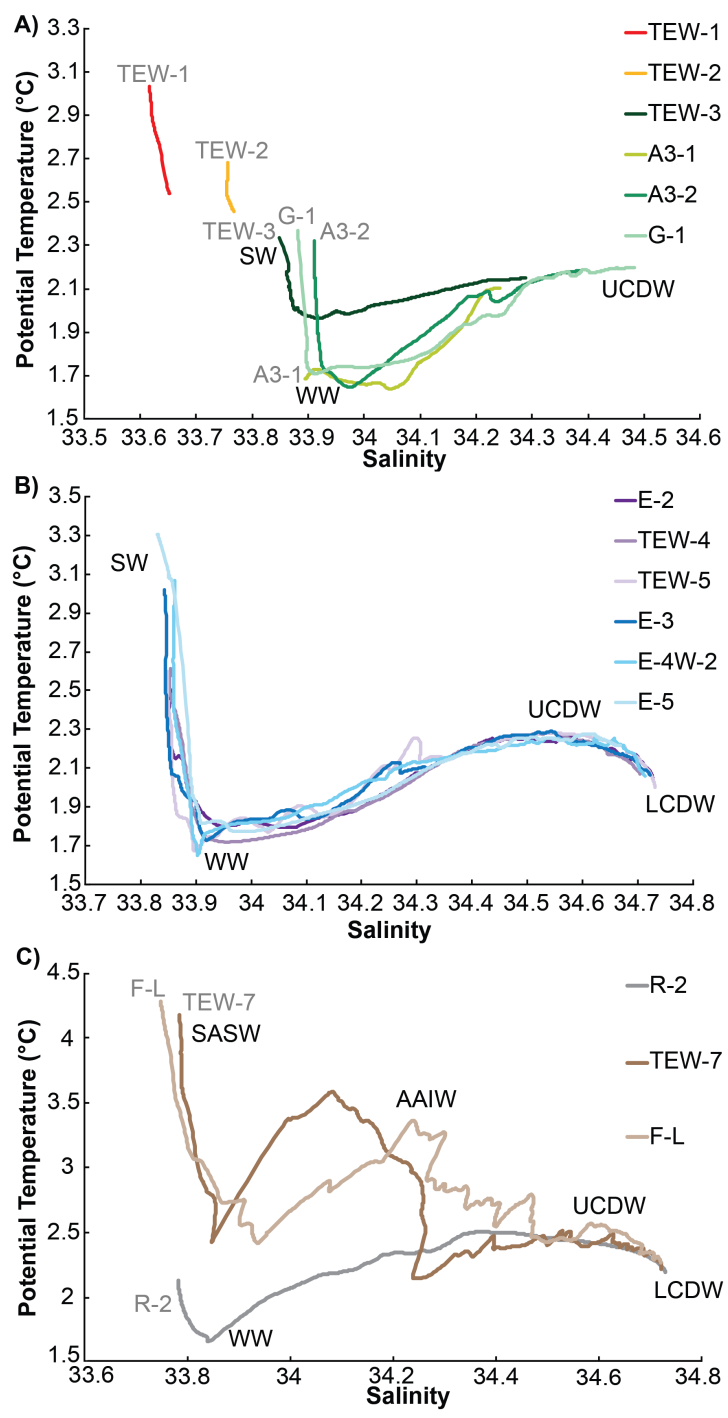

Figure 2. Potential temperature-salinity diagram for stations sampled during KEOPS2 for dissolved iron. Water masses are indicated in black, and station names in grey. The same colour code as used in Fig. 1 applies here. (a) Clusters 1 and 2: near-coastal (TEW-1, TEW-2) and Kerguelen Plateau (A3-1, A3-2, G-1, TEW-3) stations. Three water masses are displayed: surface water (SW), winter water (WW), Upper Circumpolar Deep Water (UCDW). (b) Cluster 3: the recirculation area (E-2, TEW-4, TEW-5, E-3, E-4W-2, E-5). Four water masses are displayed: surface water (SW), winter water (WW), Upper Circumpolar Deep Water (UCDW), Lower Circumpolar Deep Water (LCDW). (c) Clusters 4 and 5: north of the polar front (F-L, TEW-7) and the HNLC area (R-2). Five water masses are displayed: Subantarctic Surface Water (SASW), Antarctic Intermediate Water (AAIW), winter water (WW), Upper Circumpolar Deep Water (UCDW), Lower Circumpolar Deep Water (LCDW).

in the surface waters to the data set compiled by Tagliabue et al. (2012), R-2 had lower values than the mean value of the Indian Antarctic zone $\left(0.43 \pm 0.51 \mathrm{nmol} \mathrm{L}^{-1}\right)$, whereas the mean value in cluster 4 was higher than the mean value of the Indian subantarctic zone $\left(0.23 \pm 0.20 \mathrm{nmol} \mathrm{L}^{-1}\right)$. Tagliabue et al. (2012) suggested that the higher mean surface value in the Antarctic than in the subantarctic zone could be due to a lower biological activity in the former. In our study, the biological activity was much lower at station R-2 (Antarctic zone) than in cluster 4 (subantarctic zone). Indeed the highest integrated concentrations over $200 \mathrm{~m}$ for chlorophyll $a$ ( $\mathrm{Chl} a$ ) were observed in cluster 4 (223-35 $\mathrm{mg} \mathrm{m}^{-2}$, Lasbleiz et al., 2014). Therefore, the lower $\mathrm{dFe}$ value at R-2 compared to cluster 4 might not reflect differences in biological activity but, rather, in Fe inputs (see below).

At intermediate depths, median $\mathrm{dFe}$ values were not significantly different among clusters 2,3 , and 5 in the WW (ANOVA, $F=0.54, p=0.5904$ ), suggesting that the whole area presented similar $\mathrm{dFe}$ concentrations at the surface during wintertime. In cluster $4, \mathrm{dFe}$ in the AAIW presented relatively high values $\left(0.46 \pm 0.06 \mathrm{nmol} \mathrm{L}^{-1}\right)$, consistent with the high $\mathrm{dFe}$ values in the surface waters of the Antarctic zone (Tagliabue et al., 2012).

In the deep waters (LCDW and UCDW), stations above the plateau were enriched with $\mathrm{Fe}$ compared to all other clusters. When considering the clusters in offshore waters, values for stations in cluster $4\left(0.57 \pm 0.04 \mathrm{nmol} \mathrm{L}^{-1}\right)$ were significantly higher than those in cluster $3\left(0.41 \pm 0.09 \mathrm{nmol} \mathrm{L}^{-1}\right.$; Mann-Whitney, $W=3.0, \quad p=0.0007)$ and in cluster $5 \quad\left(0.33 \pm 0.02 \mathrm{nmol} \mathrm{L}^{-1} ; \quad\right.$ Mann-Whitney, $W=45.0$, $p=0.003$ ). This is consistent with the compilation by Tagliabue et al. (2012), which showed that deep values were higher in the subantarctic zone than in the Antarctic zone $\left(0.64 \pm 0.31\right.$ and $0.51 \pm 0.24 \mathrm{nmol} \mathrm{L}^{-1}$, respectively). This difference was attributed to both higher ligand concentrations at depth (Thuróczy et al., 2011) and deep Fe inputs such as hydrothermal activity, with the greatest input in the Indian subantarctic region (Tagliabue et al., 2012).

\subsection{Coastal area (cluster 1)}

Stations TEW-1 and TEW-2 were sampled on the same day in order to provide a nearshore data set of $\mathrm{dFe}$. Stations TEW1 and TEW-2 were in shallow waters approximately 10 and $75 \mathrm{~km}$ away from Hillsborough Bay coast, respectively.

Median profiles of $\mathrm{dFe}$, with minimum and maximum values in this cluster, are shown in Fig. 4a. At station TEW$1, \mathrm{dFe}$ concentrations were high $\left(>1.8 \mathrm{nmol} \mathrm{L}^{-1}\right.$, Table 1$)$, and increased steadily from $15 \mathrm{~m}\left(1.82 \mathrm{nmol} \mathrm{L}^{-1}\right)$ to $50 \mathrm{~m}$ depth $\left(2.58 \mathrm{nmol} \mathrm{L}^{-1}\right)$. Close to the seafloor a sharp increase at $62 \mathrm{~m}$ depth $\left(3.82 \mathrm{nmol} \mathrm{L}^{-1}\right)$ was measured. These are the highest values measured during this study. At TEW-2, dFe concentrations were lower than at TEW-1, increasing from $1.26 \mathrm{nmol} \mathrm{L}^{-1}$ in surface waters to $1.82 \mathrm{nmol} \mathrm{L}^{-1}$ at $62 \mathrm{~m}$ depth.

Several studies have already measured $\mathrm{dFe}$ at near-coastal stations in the Southern Ocean (Table 2). Around the Kerguelen Islands (KEOPS1), Crozet Islands (CROZEX), and South 


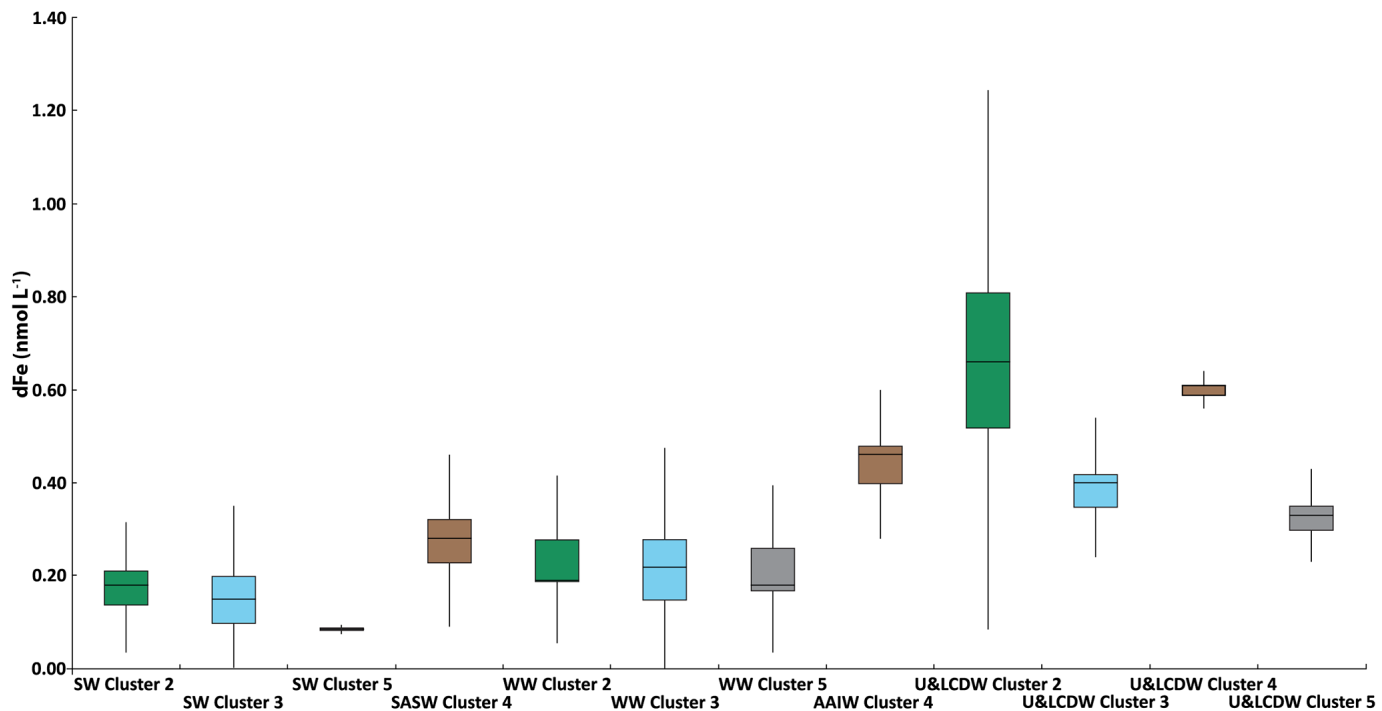

Figure 3. A box plot of the dFe concentrations in each water mass present in clusters 2 to 5 : surface waters (SW and SASW), winter waters (WW), Antarctic Intermediate Water (AAIW), and Lower and Upper Circumpolar Deep Water (LCDW and UCDW). Median values are indicated by a horizontal line within the box, the box represents the interquartile range, and the whiskers extend to 5th and 95th percentile values. Data from cluster 1 are not shown to allow a clearer representation of the other clusters.

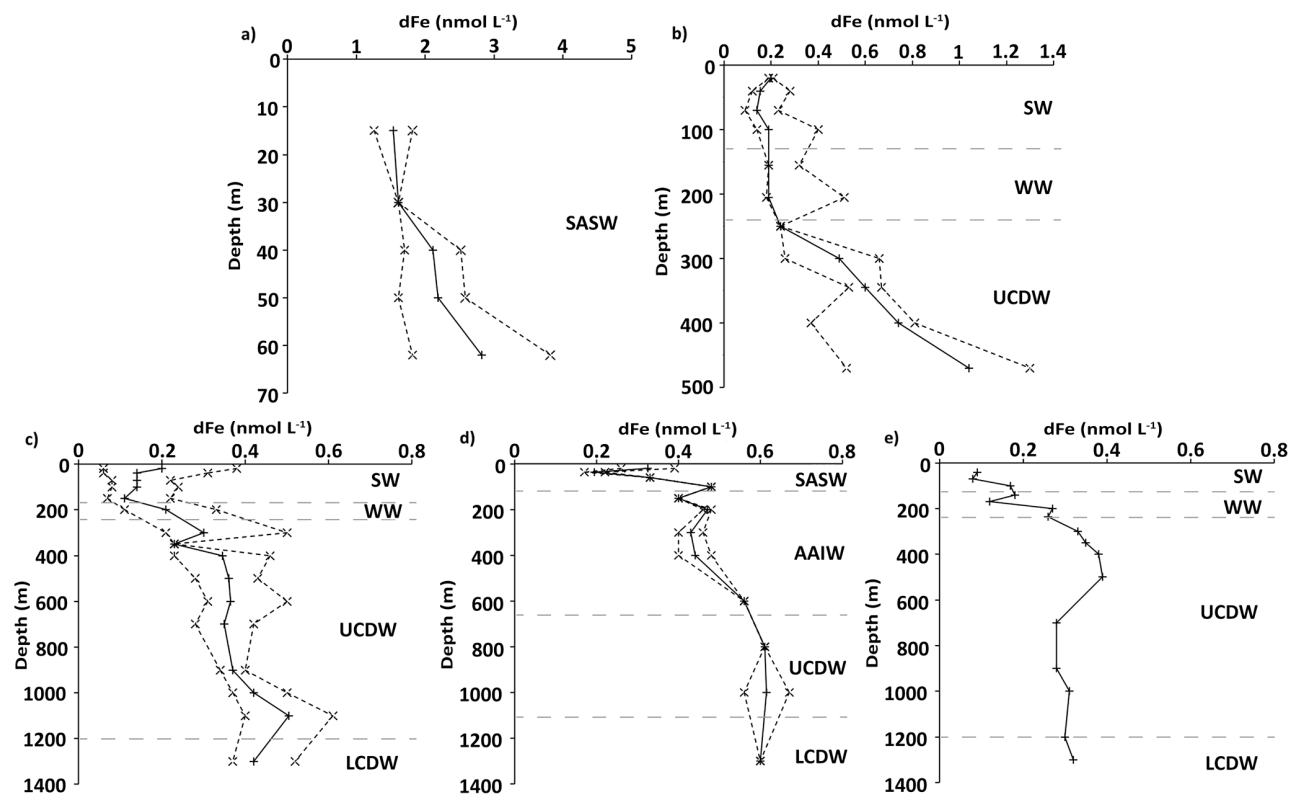

Figure 4. Vertical distribution of dFe concentrations measured in clusters 1 (a), 2 (b), 3 (c), 4 (d), and 5 (e) showing the median dFe (solid line with crosses). The interquartile range, defined as the range around the median containing $50 \%$ of the data, is given between the two dotted lines.

Shetland Islands, $\mathrm{dFe}$ concentrations were within the same order of magnitude as the present study $\left(\sim 2-4 \mathrm{nmol} \mathrm{L}^{-1}\right.$; Table 2). During ANTARES3 (Kerguelen), dFe concentrations were 5 - to 10 -fold higher $\left(22.6 \mathrm{nmol} \mathrm{L}^{-1}\right)$. This discrepancy was already discussed (Blain et al., 2008) and is likely partly due to methodological differences $(0.4 \mu \mathrm{m}$ filtration, nitric acid acidification, and 2-year storage).
The elevated $\mathrm{dFe}$ concentrations observed at nearshore sites are most certainly indicative of $\mathrm{Fe}$ sourced from the islands, a feature clearly evident during the present study and illustrated in Fig. 5. This source is most likely a combination of direct island runoff, glacial melt and resuspended sediments. High particle loads (as estimated by beam attenuation data) were encountered throughout the water col- 
Table 2. Concentrations of dissolved iron $\left(\mathrm{nmol} \mathrm{L}^{-1}\right)$ for various Southern Ocean regions influenced by natural iron fertilisation. Nearcoastal and shelf water stations were defined as stations where the bottom depth was less than $100 \mathrm{~m}$ and between 100 and $600 \mathrm{~m}$ depth, respectively. Furthermore, near-coastal stations were less than $25 \mathrm{~km}$ distant from shore. The recirculation area corresponds to the polar front meander at the north-east of the Kerguelen Islands.

\begin{tabular}{|c|c|c|c|c|c|c|c|}
\hline Location & Near-coastal & Shelf water & Recirculation & North polar front & HNLC & Sampling period & Reference \\
\hline \multirow[t]{3}{*}{ Kerguelen Islands } & $1.26-3.82$ & $0.09-1.30$ & & $0.17-0.67$ & $0.08-0.39$ & spring & This study \\
\hline & $0.78-0.81$ & $0.05-0.71$ & $0.08-0.17$ & - & $0.05-0.38$ & summer & Blain et al. (2008) \\
\hline & $5.04-22.60$ & $0.26-1.74$ & $0.46-2.71$ & $0.88-4.11$ & - & spring & Bucciarelli et al. (2001) \\
\hline Crozet Islands & $0.39-2.16$ & $0.15-0.42$ & - & $0.22-0.38$ & $0.20-0.40$ & late spring & Planquette et al. (2007) \\
\hline South Georgia & - & $0.065-1.321$ & - & - & - & summer & Nielsdóttir et al. (2012) \\
\hline South Orkney Islands & $0.966-2.275$ & - & - & - & - & summer & Nielsdóttir et al. (2012) \\
\hline \multirow[t]{2}{*}{ South Shetland Islands } & $>3$ & $1.2-2.6$ & - & - & - & winter & Hatta et al. (2013) \\
\hline & $0.8-2.2$ & - & - & - & - & late summer & Klunder et al. (2014) \\
\hline
\end{tabular}

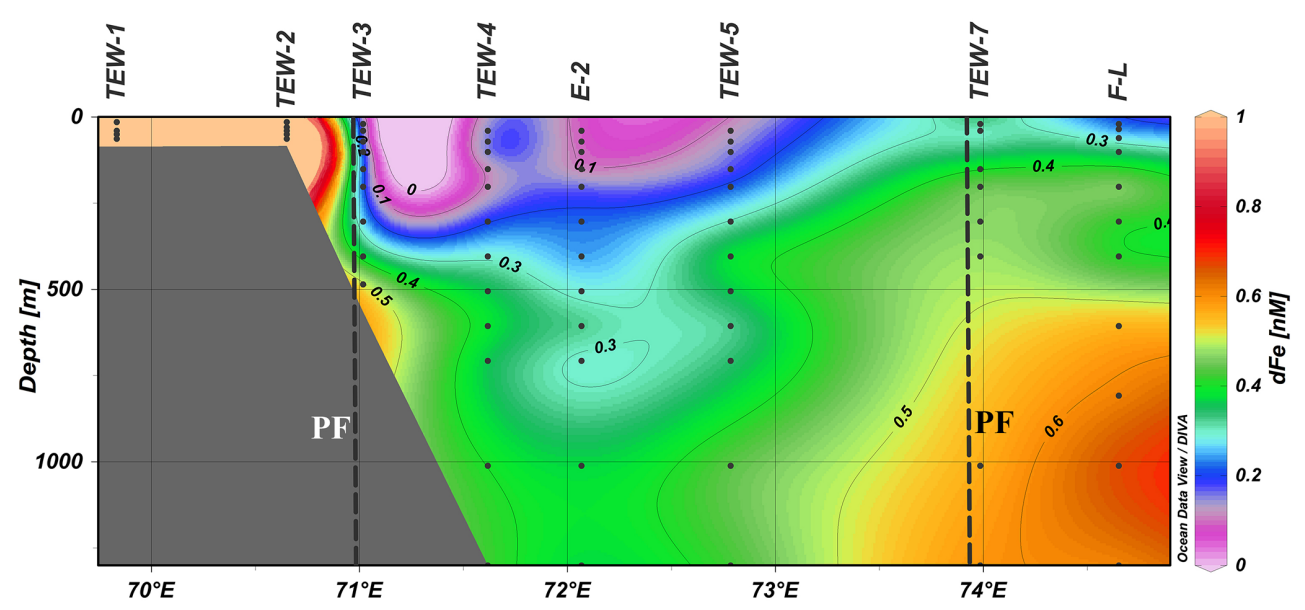

Figure 5. Concentrations of $\mathrm{dFe}\left(\mathrm{nmol} \mathrm{L}^{-1}\right)$ over the east-west transect. The PF position is indicated with black dashed lines. Stations TEW-1, TEW-2, TEW-3, TEW-4, E-2, TEW-5, TEW-7, and F-L were included in this section as they were sampled consecutively in a short time period (7 days) (Table 1).

umn of TEW-1 and TEW-2, with higher concentrations at TEW-1, especially at $10 \mathrm{~m}$ depth and close to the seafloor (Fig. 6). Low salinities ( $33.63 \pm 0.01, n=61)$ were also measured at TEW-1, which corroborates our hypothesis of direct island runoff and/or glacial melt inputs. Moreover, the Ampère Glacier, which is the largest glacier from the Cook Ice Cap (about $500 \mathrm{~km}^{2}$ ), has thinned rapidly over the last decade (Berthier et al., 2009), especially towards the east of the ice cap, up to $1.5 \mathrm{~m}$ per year. This discharge includes small basalt-derived particles (Frenot et al., 1995) and could partially discharge in Hillsborough Bay (Y. Frenot, personal communication, 2014). Finally, TEW-1 showed the highest lithogenic silica (LSi) concentrations of the study area $\left(1.31 \pm 0.14 \mu \mathrm{mol} \mathrm{L}^{-1}\right.$; Closset et al., 2014; Lasbleiz et al., 2014) and TEW-2 showed slightly lower LSi concentrations $\left(0.54 \pm 0.02 \mu \mathrm{mol} \mathrm{L}^{-1}\right)$. Gradients in LSi and $\mathrm{dFe}$ are probably indicative of glacial melt inputs, Fe being leached from nanoparticulate iron (oxyhydr)oxides present in glacial rock flour (Raiswell et al., 2010; Raiswell, 2011) and LSi being weathered from silicate-rich minerals $\left(\mathrm{SiO}_{2}\right.$; Doucet et al., 2005).

Sedimentary inputs (e.g. Johnson et al., 1999; Elrod et al., 2004; Chase et al., 2005; Lam et al., 2006; Planquette et al., 2011; Homoky et al., 2013; Marsay et al., 2014) could also explain the increased $\mathrm{dFe}$ concentrations encountered at both stations close to the seafloor $\left(3.82\right.$ and $1.82 \mathrm{nmol} \mathrm{L}^{-1}$ at stations TEW-1 and TEW-2, respectively). Unfortunately, particulate $\mathrm{Fe}(\mathrm{pFe})$ concentrations were not measured at these near-coastal locations to confirm sediment resuspension, but the fact that the beam attenuation increased close to the seafloor of station TEW-1 (Fig. 6) and that high dMn concentrations at TEW-1 $\left(5.40 \mathrm{nmol} \mathrm{L}^{-1}\right)$ and TEW-2 $\left(1.92 \mathrm{nmol} \mathrm{L}^{-1}\right)$ were also measured (Quéroué et al., unpublished data) strongly supports this hypothesis.

Dissolved Fe concentrations in the water column may reflect not only sedimentary inputs but also inputs from remineralisation processes. However, since deciphering remineralisation from sedimentary inputs at shallow stations is diffi- 

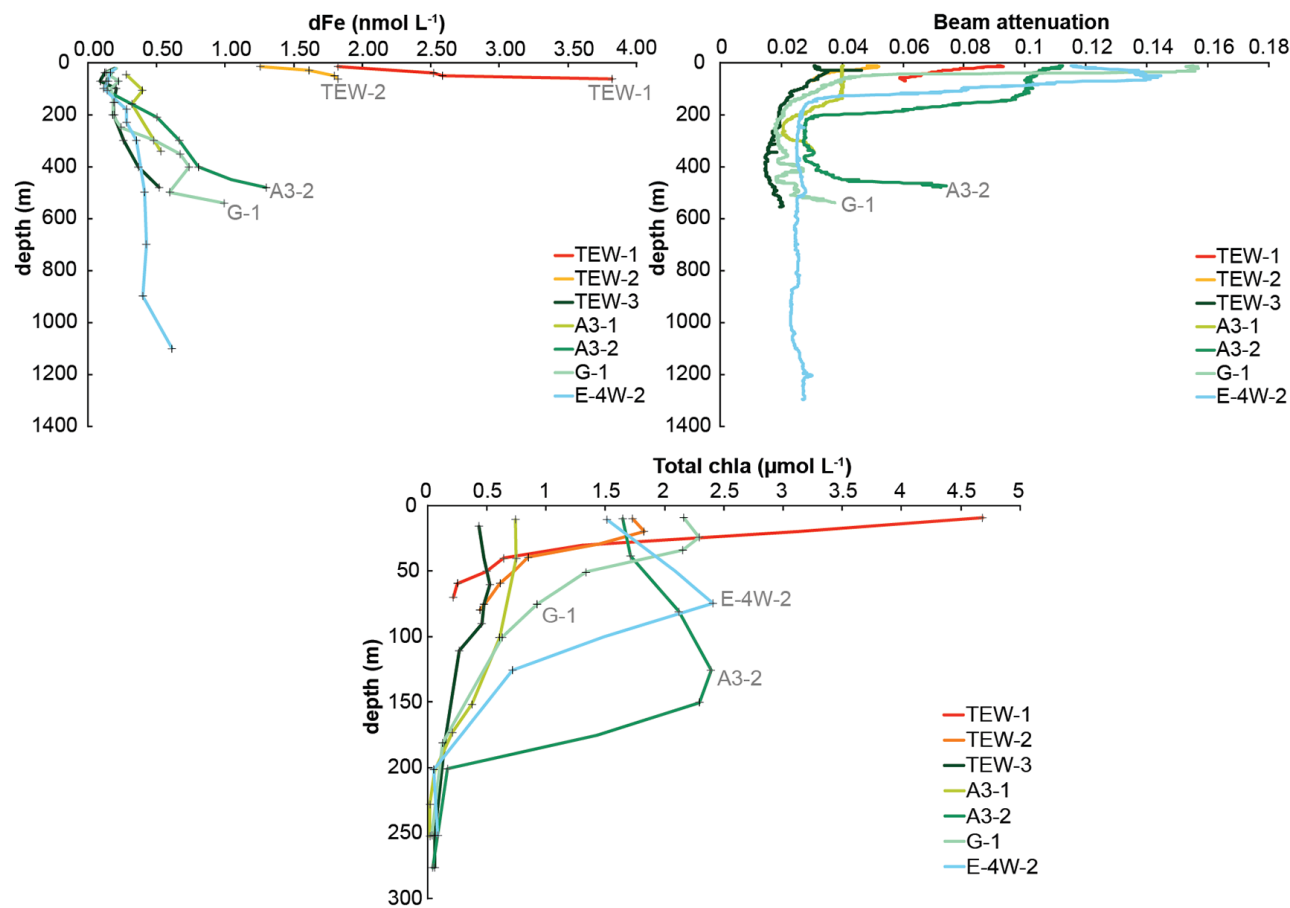

Figure 6. (a) Dissolved Fe concentrations, (b) beam attenuation coefficient, and (c) total chlorophyll $a$ concentrations (from Lasbleiz et al., 2014) at near-coastal stations (cluster 1, TEW-1, and TEW-2), stations above the plateau (cluster 2, A3-1, A3-2, G-1, and TEW-3), and at E-4W-2. The same colour code as used in Fig. 1 applies here.

cult, remineralisation process will only be discussed for clusters 3,4 , and 5 .

\subsection{Central plateau area (cluster 2)}

Similar $\mathrm{dFe}$ vertical profiles were observed at A3-2, G1, and TEW-3 with low dFe concentrations at the surface $\left(\sim 0.1-0.2 \mathrm{nmol} \mathrm{L}^{-1}\right)$, increasing towards the bottom, up to $1.30 \pm 0.01,0.99 \pm 0.01$, and $0.37 \pm 0.00 \mathrm{nmol} \mathrm{L}^{-1}$, respectively (Table 1). Median profiles of $\mathrm{dFe}$, with minimum and maximum values in this cluster, are shown in Fig. 4b. At station A3-1, concentrations were higher in the SML $(\sim 0.3-$ $0.4 \mathrm{nmol} \mathrm{L}^{-1}$ ) and then increased with depth below the SML up to $0.40 \pm 0.01 \mathrm{nmol} \mathrm{L}^{-1}$ at $350 \mathrm{~m}$.

Over the Kerguelen Plateau, 24 shelf stations have been investigated during several cruises (Table 2). The highest concentrations were measured during ANTARES3 $\left(\sim 6 \mathrm{nmol} \mathrm{L}{ }^{-1}\right)$ in the northern part of the Kerguelen Plateau at a station located $76 \mathrm{~km}$ away from the shore (station $\mathrm{K} 4,40 \mathrm{~m})$. The lowest concentrations were measured during KEOPS $1\left(0.05 \mathrm{nmol} \mathrm{L}^{-1}\right)$ within the top $200 \mathrm{~m}$ of water. Above $100 \mathrm{~m}$, lower concentrations were observed during KEOPS1 compared to KEOPS2 (Table 2). This can be explained by a more advanced phytoplankton bloom during KEOPS1 (summer conditions) than KEOPS2 (spring conditions). In surface waters, $\mathrm{dFe}$ concentrations measured during KEOPS2 were of similar magnitude to those measured in the vicinity of the South Shetland Islands (Nielsdóttir et al., 2012; Table 2).

A deep Fe-enriched reservoir was also observed above the Kerguelen Plateau during KEOPS1 (Blain et al., 2008; Chever et al., 2010). Non-reductive dissolution of resuspended sediments is a potentially important source of $\mathrm{dFe}$ as observed at near-coastal stations (e.g. Homoky et al., 2013). At station A3, high LSi concentrations $\left(1.34 \pm 0.07 \mu \mathrm{mol} \mathrm{L}^{-1}\right.$; Lasbleiz et al., 2014) were observed just above the seafloor in the benthic boundary layer (BBL), also suggesting sedimentary inputs. This is corroborated by high $\mathrm{pFe}$ values at A3-1 and A3-2 (30 and $15 \mathrm{nmol} \mathrm{L}^{-1}$, respectively) and $\mathrm{pFe}: \mathrm{pAl}$ ratios that resemble basalt over the Kerguelen Plateau (van der Merwe et al., 2015).

The variability in the deep $\mathrm{dFe}$ concentrations above the plateau may be due to variability in sedimentary inputs in this highly dynamic region. All stations from this cluster except station TEW-3 had high beam attenuation values close to the seafloor, which most likely indicates the presence of resuspended particles at these depths (98\% for TEW-3 vs. $92-97 \%$ for the other three stations, Fig. 6). Marsay et al. (2014) performed a very detailed sampling of near-bottom waters for $\mathrm{dFe}$ over the Ross Sea shelf and showed that $\mathrm{dFe}$ concentrations displayed a quasi-exponential increase with depth, with a pronounced gradient towards the seafloor. When plotting our dFe data as a function of height above the seafloor, we also observed an exponential increase with depth 


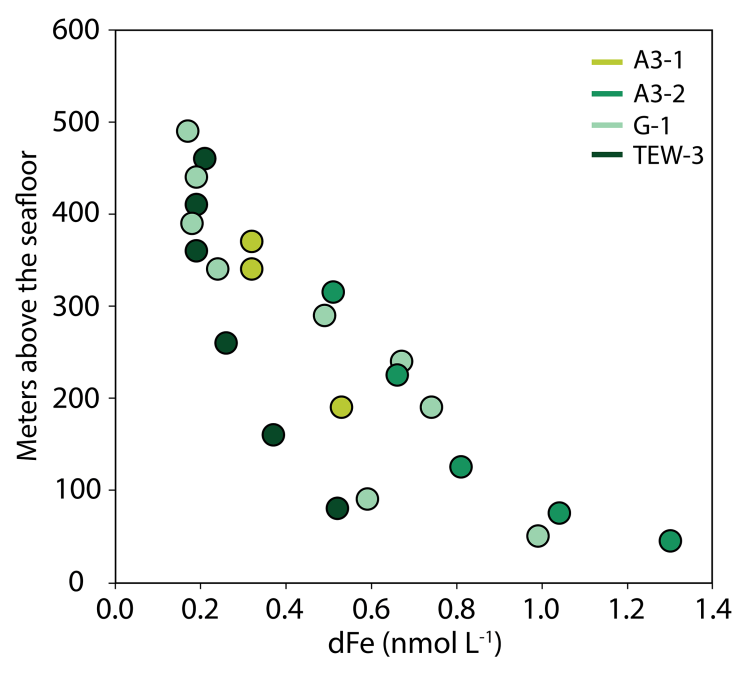

Figure 7. Dissolved Fe concentrations as a function of height above seafloor for all the stations of cluster 2. Bottom depths are taken from the CTD data. The same colour code as used in Fig. 1 applies here.

(Fig. 7). Clearly, the least pronounced gradient between $\mathrm{dFe}$ and height above seafloor was observed at station TEW-3.

Hydrothermal input may be an additional Fe source above the Kerguelen Plateau, more particularly in the vicinity of the Heard Island. The $\mathrm{Mn}: \mathrm{Al}$ ratio at this station is much lower than at any of the other stations 0.007-0.009 (van der Merwe et al., 2015) and very similar to the Kerguelen Islands basalt mean of 0.004-0.010 (Gautier et al., 1990). This supports fresh weathering of basalt downstream of A3, which may be glacial/fluvial runoff or hydrothermal.

Diffusion from pore waters is another important possible source of Fe for the BBL (Elrod et al., 2004). When sediment receives large amount of organic carbon, it is covered by a fluff layer composed mainly of broken cells, as observed during KEOPS1 for stations above the plateau (Armand et al., 2008). Diagenesis then produces suboxic/anoxic conditions, which are key conditions to mobilise Fe because of the high solubility of the reduced Fe(II) form (Walsh et al., 1988). Anoxic conditions were observed $2 \mathrm{~cm}$ below the sediment surface at the A3 stations (P. Anschutz, personal communication, 2014), suggesting that, in pore waters above the plateau, Fe could be in the reduced form and diffuse into the bottom water column.

For all stations in cluster $2, \mathrm{dFe}$ minima were observed in the SML, which could reflect biological uptake and/or particle scavenging. A significant decrease was observed in $\mathrm{dFe}$ concentrations in the SML between A3$1\left(0.33 \pm 0.06 \mathrm{nmol} \mathrm{L}^{-1}\right)$ and A3-2 $\left(0.15 \pm 0.02 \mathrm{nmol} \mathrm{L}^{-1}\right)$ ( $t$ test, $p<0.05$ ). The first visit to site A3 (A3-1, 20 October) was characteristic of early bloom conditions, while during the second visit 28 days later (A3-2, 17 November), chlorophyll $a$ concentrations at the sea surface increased by about
3 -fold as a consequence of a large diatom bloom (Fig. 6c) (Lasbleiz et al., 2014). Moreover, based on the beam attenuation profiles, A3-2 seemed to have more particles (likely of biogenic origin) than A3-1 within the top $200 \mathrm{~m}$. This is confirmed by the fact that at these depths, the $\mathrm{Fe}$ : Al ratio at A3-2 is higher than A3-1 and in all cases, well above the crustal ratios. This may indicate that more $\mathrm{pFe}$ of biogenic origin was present at A3-2 than at A3-1 (van der Merwe et al., 2015), and confirm an increased biological uptake at A3-2 compared to A3-1. Between the two visits, integrated dFe concentrations over $200 \mathrm{~m}$ decreased (62.6 vs. $28.1 \mu \mathrm{mol} \mathrm{m}{ }^{-2}$ ), while concentrations of particulate organic carbon (POC) (from 1259 to $2267 \mathrm{mmolC} \mathrm{m}^{-2}$ ) increased (Lasbleiz et al., 2014). The decrease in $\mathrm{dFe}$ stock represents $\sim 35 \%$ of the winter stock, defined as the $\mathrm{dFe}$ concentration in the WW $\left(0.51 \mathrm{nmol} \mathrm{L}^{-1}\right)$ multiplied by the depth of the temperature minimum (200 m) (Blain et al., 2007). Taking into account the decrease in $\mathrm{dFe}$ stock and the increase in POC stock, the $\mathrm{Fe}: \mathrm{C}$ ratio of the biomass that developed between the two visits at $\mathrm{A} 3$ can be estimated to equal $34 \mu \mathrm{mol} \mathrm{mol}^{-1}$, a ratio consistent with literature values for diatoms in Fe-replete waters of the Southern Ocean (Sunda and Huntsman, 1995; Sunda, 1997; Twining et al., 2004; Sarthou et al., 2005). Although this is a rough estimate which does not take into account any additional inputs or removal processes, this result indicates that the dFe decrease between A3-1 and A3-2 could be due, at least partly, to biological uptake.

\subsection{Recirculation area (cluster 3)}

Median profiles of $\mathrm{dFe}$, with minimum and maximum values in this cluster, are shown in Fig. 4c. A two-way ANOVA, based on depth and location (i.e. station), showed that location had a significant effect on dFe variability $(F=24.92$, $\mathrm{d} f=5, P<0.01)$. It defined five homogeneous groups from the six stations tested (E-2/E-5, E-5/TEW-4, TEW-4/TEW5, TEW-5/E-4W-2, and E-3), showing the strong variability in vertical $\mathrm{dFe}$ distributions in this cluster. Stations E-2 and E-5 showed very low concentrations near the sea surface (from 0.06 to $0.10 \mathrm{nmol} \mathrm{L}^{-1}$ ) and a gradual increase with depth $\left(\sim 0.37-0.39 \mathrm{nmol} \mathrm{L}^{-1}\right.$, at $\left.1300 \mathrm{~m}\right)$ (Table 1). A dFe maximum was observed at intermediate depths $(500-600 \mathrm{~m}$, $\left.0.34-0.43 \mathrm{nmol} \mathrm{L}^{-1}\right)$. The dFe profile at station TEW-4 is homogeneous below $150 \mathrm{~m}$. The $\mathrm{dFe}$ maximum at $600 \mathrm{~m}$ is $0.39 \mathrm{nmol} \mathrm{L}^{-1}$ and, at $1300 \mathrm{~m}, \mathrm{dFe}$ reaches $0.42 \mathrm{nmol} \mathrm{L}^{-1}$.

Concentrations at stations TEW-5 and E-4W-2 were close to those at stations TEW-4 in the upper $150 \mathrm{~m}$ $\left(0.11-0.22 \mathrm{nmol} \mathrm{L}^{-1}\right)$, but these stations showed higher concentrations at intermediate depths $(150-200 \mathrm{~m}, 0.21-$ $0.30 \mathrm{nmol} \mathrm{L}^{-1}$ ). Below $150-200 \mathrm{~m}$, concentrations reached values of $\sim 0.4 \mathrm{nmol} \mathrm{L}^{-1}$, except for the deepest value at station E-4W-2 (0.61 $\left.\pm 0.02 \mathrm{nmol} \mathrm{L}^{-1}, 1100 \mathrm{~m}\right)$. This sampling depth was located less than $200 \mathrm{~m}$ away from the seafloor and was associated with an increase in beam attenuation (see 
Fig. 6), which indicated a high number of particles and potential sedimentary inputs.

Station E-3 had high surface $\mathrm{dFe}$ concentrations at $40 \mathrm{~m}\left(0.38 \pm 0.03 \mathrm{nmol} \mathrm{L}^{-1}\right)$ followed by a minimum at $100 \mathrm{~m}\left(0.22 \pm 0.01 \mathrm{nmol} \mathrm{L}^{-1}\right)$ (Table 1). A subsurface $\mathrm{dFe}$ maximum was observed at intermediate depth $(300 \mathrm{~m}$, $\left.0.50 \pm 0.01 \mathrm{nmol} \mathrm{L}^{-1}\right)$, while concentrations remained homogenous at deeper depths $\left(0.52 \pm 0.01 \mathrm{nmol} \mathrm{L}^{-1}\right)$.

In this cluster, $\mathrm{dFe}$ concentrations were comparable to concentrations measured at stations off the Crozet Plateau that were not under HNLC conditions (Planquette et al., 2007). However during KEOPS2, water column $\mathrm{dFe}$ concentrations were lower than those observed during ANTARES 3 and in the South Shetland Islands sites, most likely due to the greater distance of the KEOPS2 stations from the shore (Table 2).

The higher sea-surface $\mathrm{dFe}$ concentrations at stations TEW-4, E-4W-2, and E-3, may be indicative of atmospheric inputs. However, no particulate aluminium (pAl, a proxy for atmospheric inputs) surface enrichment in the recirculation area was observed during the study (van der Merwe et al., 2015), suggesting that air masses were not carrying enough aerosols to enhance pAl surface concentrations. Moreover, Bowie et al. (2014) showed that atmospheric inputs were of the order of $50 \mathrm{nmol} \mathrm{m}^{-2} \mathrm{~d}^{-1}$, which is insignificant compared to the lateral supply of $\mathrm{dFe}$ in the same area (180$2400 \mathrm{nmol} \mathrm{m}^{-2} \mathrm{~d}^{-1}$ ). Significant ${ }^{224} \mathrm{Ra}$ and ${ }^{223} \mathrm{Ra}$ activities were detected in offshore waters south of the PF (Sanial et al., 2015). These observations clearly indicated that dissolved sediment-derived inputs of Ra can be rapidly transferred towards offshore waters. These Ra-enriched waters could also be enriched with dissolved sediment-derived Fe.

Within the waters characterised by an oxygen minimum, remineralisation of sinking organic matter may exert a primary control on $\mathrm{dFe}$ distribution. To assess this hypothesis, we looked at the relationship between $\mathrm{dFe}$ and the apparent oxygen utilisation (AOU), from the start of the oxycline $(\sim 150-200 \mathrm{~m})$ to the bottom of the UCDW $(700-1100 \mathrm{~m})$. In these waters, the AOU indicates the amount of oxygen that has been consumed during remineralisation since the waters left the surface, whereas dFe concentration equals the preformed $\mathrm{dFe}$ plus any $\mathrm{dFe}$ released from remineralisation, minus any $\mathrm{dFe}$ scavenged by particles (Hatta et al., 2015). Dissolved Fe concentrations showed a significant positive correlation with the AOU for all the stations in the recirculation area (ANOVA, $p<0.01$ ), meaning that remineralisation was likely a significant source of $\mathrm{dFe}$ at these depths. Station E-3 clearly presented a different behaviour compared to the other stations of cluster 3 (Fig. 8). Indeed, although the slopes were not significantly different $\left(0.0016 \pm 0.0003 \mathrm{mmol} \mathrm{mol}^{-1}\right.$ for E-3 and $0.0018 \pm 0.0002 \mathrm{mmol} \mathrm{mol}^{-1}$ for all stations except E-3; ANOVA, $p>0.1$ ), the intercepts were different $\left(0.26 \pm 0.05 \mathrm{nmol} \mathrm{L}^{-1}\right.$ for E-3 and $0.08 \pm 0.03 \mathrm{nmol} \mathrm{L}^{-1}$ for all the other stations; ANOVA, $p<0.01)$. This suggests that a preformed $\mathrm{dFe}$ signal was present at E-3, which could ex-

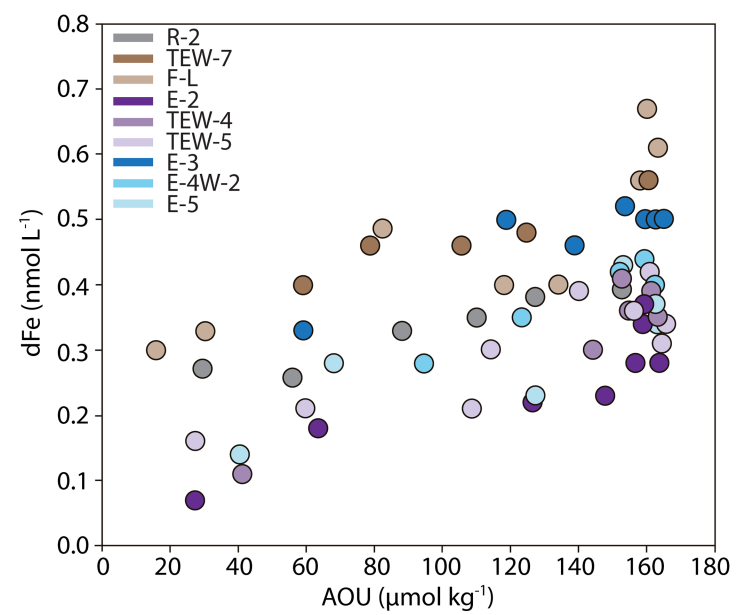

Figure 8. dFe vs. AOU in the recirculation area at stations E-2, E-5, TEW-4, TEW-5, E-4W-2, E-3, R-2, TEW-7, and F-L. The deeper $\mathrm{dFe}$ concentration at station E-4W-2 was not included since the observed sedimentary inputs would have masked the remineralisation signal. The same colour code as used in Fig. 1 applies here.

plain the highest $\mathrm{dFe}$ values observed at this station. Using this slope of the $\mathrm{dFe}-\mathrm{AOU}$ relationship and a modified oxygen consumption ratio of 1.6 moles of $\mathrm{O}_{2}$ per mole of carbon remineralised (Martin et al., 1987), a net $\mathrm{Fe}: \mathrm{C}$ ratio for the remineralisation process equal to $2.6-2.9 \mu \mathrm{mol} \mathrm{mol}^{-1}$ was estimated. This ratio is very similar to $\mathrm{Fe}: \mathrm{C}$ ratios of Fe-limited diatoms from culture studies and in situ Southern Ocean data (Martin et al., 1987; Sunda, 1997; Sarthou et al., 2005).

\subsection{North polar front stations (cluster 4)}

Stations TEW-7 and F-L were located north-east of the $\mathrm{PF}$, approximately 270 and $313 \mathrm{~km}$ north-east of the Kerguelen Islands, with bottom depths of 2500 and $2700 \mathrm{~m}$, respectively. These stations presented comparable vertical profiles (Fig. 4d). In the upper $50 \mathrm{~m}, \mathrm{dFe}$ concentrations were depleted at 0.22 and $0.17 \mathrm{nmol} \mathrm{L}^{-1}$ (at $40 \mathrm{~m}$ at station TEW-7 and $35 \mathrm{~m}$ at station F-L, respectively) and then gradually increased within the mesopelagic zone to finally reach $0.59 \mathrm{nmol} \mathrm{L}^{-1}$ at $1300 \mathrm{~m}$ depth (station TEW-7) and $0.67 \mathrm{nmol} \mathrm{L}^{-1}$ at $1000 \mathrm{~m}$ depth (station F-L).

During ANTARES 3, station K14, which was also sampled north-east of the PF, exhibited high values at the surface (4.11 $\mathrm{nmol} \mathrm{L}^{-1}$ at $40 \mathrm{~m}$ depth). This was interpreted as the result of a mixing between SASW and water masses coming from the west and enriched by sweeping the plateau (Bucciarelli et al., 2001), at a time when no significant sink occurred (beginning of spring, $\sim 0.4 \mu \mathrm{g} \mathrm{L}^{-1}$ of Chl $a$ ).

During KEOPS2, however, the decrease in $\mathrm{dFe}$ concentrations within the SASW, around $35-40 \mathrm{~m}$ depth, can result from biological uptake. This is suggested by the high biomass reported at stations TEW-7 and F-L 
(Lasbleiz et al., 2014), with the highest integrated concentrations over $200 \mathrm{~m}$ for $\mathrm{Chl} a\left(>220 \mathrm{mg} \mathrm{m}^{-2}\right)$, biogenic silica $\left(>300 \mathrm{mmol} \mathrm{Si} \mathrm{m}^{-2}\right.$ ), particulate organic carbon $\left(>1200 \mathrm{mmol} \mathrm{C} \mathrm{m}^{-2}\right)$, particulate organic nitrogen (>200 $\mathrm{mmol} \mathrm{N} \mathrm{m}^{-2}$ ), and particulate organic phosphorus (> $30 \mathrm{mmol} \mathrm{P} \mathrm{m}^{-2}$ ). This biological uptake is also reflected in the composition of suspended particles (van der Merwe et al., 2015). In surface waters, higher $\mathrm{pFe}$ : $\mathrm{pAl}$ elemental ratios were observed compared to those from the base of the SML, which is indicative of a conversion of dFe into biogenic $\mathrm{pFe}$. However, compared to the less productive recirculation area (see Sect. 3.5), the surface dFe concentrations are higher by $0.1 \mathrm{nmol} \mathrm{L}^{-1}$. This could be explained by the fact that, like during ANTARES 3, a portion of the water masses found at TEW-7 and F-L likely interacted more with both the plateau and shallow coastal waters of the Kerguelen Islands than the water masses from the recirculation area. This hypothesis is supported by the general circulation in this region (Park et al., 2014) that shows that water masses are carried northwards between the island and the recirculation area and finally looped back east of the recirculation area. A Lagrangian model of $\mathrm{Fe}$ transport based on altimetry (d'Ovidio et al., 2015) also confirms that the waters at F-L and TEW-7 are mainly coming from the northern part of plateau. Moreover, close to the seafloor, van der Merwe et al. (2015) observed high values of $\mathrm{pFe}, \mathrm{pMn}$, and pAl, likely due to sediment resuspension.

As for the recirculation area, $\mathrm{dFe}$ concentrations in the mesopelagic zone may also reflect remineralisation processes. Dissolved $\mathrm{Fe}$ concentrations present a significant positive relationship with AOU for both stations $\quad(\mathrm{dFe}=0.0014 \pm 0.0003 \times \mathrm{AOU}+0.32 \pm 0.03$, $n=5, \quad r^{2}=90 \%, \quad p<0.05$ for station TEW-7; $\mathrm{dFe}=0.0020 \pm 0.0005 \times \mathrm{AOU}+0.24 \pm 0.07, \quad n=7$, $r^{2}=74 \%, p<0.05$ for station F-L). The two slopes are not significantly different (ANOVA, $p>0.1$ ). When combining the two data sets (Fig. 8), the slope is also not significantly different from the slope in the recirculation area (ANOVA, $p>0.1$ ), suggesting that $\mathrm{Fe}$ and $\mathrm{C}$ are remineralised at the same rates in both regions $\left(\mathrm{Fe}: \mathrm{C} \sim 2 \mu \mathrm{mol} \mathrm{mol}^{-1}\right.$ ). However, the intercept is significantly different from the intercept of the recirculation area (without the station E-3; see above) and from zero (ANOVA, $p<0.01$ ), suggesting the presence of preformed $\mathrm{Fe}$ in these waters.

\subsection{The HNLC station (cluster 5)}

At station $\mathrm{R}-2$, $\mathrm{dFe}$ concentrations were low within surface waters $\left(\sim 0.1 \mathrm{nmol} \mathrm{L}^{-1}\right)$ and highest at $500 \mathrm{~m}$ depth $\left(0.39 \mathrm{nmol} \mathrm{L}^{-1}\right)$ (Fig. 4e). Below $500 \mathrm{~m}$, dFe concentrations decreased to a value of $\sim 0.30 \mathrm{nmol} \mathrm{L}^{-1}$.

The KEOPS, CROZEX, and South Shetland Islands studies (Planquette et al., 2007; Blain et al., 2008; Nielsdóttir et al., 2012) presented comparable ranges of $\mathrm{dFe}$ at open-ocean stations (Table 2). Dissolved Fe concentrations at R-2 were similar to those observed during KEOPS1 at $\mathrm{C} 11$ and the Kerfix station within the upper $170 \mathrm{~m}$ of the water column, as well as between 700 and $1300 \mathrm{~m}$ (Blain et al., 2008). However, $\mathrm{dFe}$ concentrations were up to 6.5-fold higher between 200 and $500 \mathrm{~m}$ at R-2 compared to C-11 and Kerfix, despite the close proximity of Kerfix and R-2.

While sea-surface lithogenic silica (LSi) concentrations (Lasbleiz et al., 2014) were low at station R-2 $\left(<0.042 \mu \mathrm{mol} \mathrm{L}^{-1}\right)$, they were maximum at $500 \mathrm{~m}$ depth $\left(0.12 \mu \mathrm{mol} \mathrm{L}^{-1}\right)$. Particulate iron, manganese, and aluminium (fraction between 1 and $55 \mu \mathrm{m}$ ) enrichments were also observed at $500 \mathrm{~m}$ (van der Merwe et al., 2015). Van der Merwe et al. (2015) also observed a unique particulate trace metal composition signature at this station, which could originate from the Leclaire Rise, contrasting with the basaltic signature observed above the Kerguelen Plateau (Doucet et al., 2005). The Leclaire Rise is a remarkable oceanic feature that consists of a submerged volcano with an area of $6500 \mathrm{~km}^{2}$, with the shallowest depth up to $100 \mathrm{~m}$. It is located $75 \mathrm{~km}$ north-west of R-2 and could release dissolved and particulate material.

Similar to clusters 3 and 4 , remineralisation may also partly explain $\mathrm{dFe}$ concentrations in the mesopelagic zone $(\mathrm{dFe}=0.0012 \pm 0.0002 \times \mathrm{AOU}+0.22 \pm 0.02, n=6$, $\left.r^{2}=91.8 \%, p<0.01\right)$. Fe and $\mathrm{C}$ are also remineralised at the same rates as in clusters 3 and 4 (ANOVA, $p>0.1$ ), and the intercept, significantly different from zero (ANOVA, $p<0.01$ ), confirms the hypothesis of $\mathrm{dFe}$ sedimentary inputs at this station.

\section{Conclusions}

This third cruise over the Kerguelen Plateau allowed new insights into dFe sources and internal cycling. Direct runoff and glacial and sedimentary inputs can all be considered as important sources of $\mathrm{dFe}$ in the vicinity of the Kerguelen Islands. Remineralisation of sinking particles can explain the high concentrations of $\mathrm{dFe}$ in intermediate waters offshore. The strong jet of the PF was enriched with $\mathrm{dFe}$ from the north of the plateau as it flowed northward close to the Kerguelen Islands and later eastward to loop back into the recirculation area. This fertilised surface waters of the eastern part of the studied area. Furthermore, filaments crossing the $\mathrm{PF}$ allowed a more direct natural $\mathrm{Fe}$ fertilisation of surface water in the recirculation area. Due to variable water mass origin and variable horizontal advection mechanism (along or across the PF), the recirculation area evidenced strong $\mathrm{dFe}$ concentration variability. The PF is an important Southern Ocean feature that should not be neglected with regards to Southern Ocean fertilisation offshore from the Kerguelen Plateau through fast lateral $\mathrm{Fe}$ transport from the north of the Kerguelen Plateau. 
Acknowledgements. The authors thank the crew of the R/V Marion Dufresne for assistance on board and Bernard Quéguiner, the chief scientist. They also greatly acknowledge Young-Hyang Park for fruitful discussions about the complex hydrography of the studied area. The authors thank the two anonymous referees for their fruitful comments. This work was supported by the French research programme of INSU-CNRS LEFE-CYBER ("Les enveloppes fluides et l'environnement" - "Cycles biogéochimiques, environnement et ressources"), the French ANR ("Agence Nationale de la Recherche", SIMI-6 programme, ANR-2010-BLAN-614 KEOPS2, and ANR-10-JCJC-606 ICOP), the French CNES programme ("Centre National d'Etudes Spatiales"), and the French Polar Institute IPEV (Institut Polaire Paul-Emile Victor). This research was supported by University of Tasmania Cross Theme (B0018994) and Rising Stars (B0019024) grants. Thanks to the Antarctic Climate and Ecosystems Cooperative Research Centre (ACE CRC) for funding participation in the KEOPS2 study through the Carbon programme. The KEOPS2 experiment was approved as a GEOTRACES process study.

Edited by: I. Obernosterer

\section{References}

Ardelan, M. V., Holm-Hansen, O., Hewes, C. D., Reiss, C. S., Silva, N. S., Dulaiova, H., Steinnes, E., and Sakshaug, E.: Natural iron enrichment around the Antarctic Peninsula in the Southern Ocean, Biogeosciences, 7, 11-25, doi:10.5194/bg-7-11-2010, 2010.

Armand, L. K., Cornet-Barthaux, V., Mosseri, J., and Quéguiner, B.: Late summer diatom biomass and community structure on and around the naturally iron-fertilised Kerguelen Plateau in the Southern Ocean, Deep-Sea Res. Pt. II, 55, 653-676, 2008.

Berthier, E., Le Bris, R., Mabileau, L., Testut, L., and Rémy, F.: Ice wastage on the Kerguelen Islands (49S, 69E) between 1963 and 2006, J. Geophys. Res.-Earth, 114, F03005, doi:10.1029/2008JF001192, 2009.

Blain, S., Quéguiner, B., Armand, L., Belviso, S., Bombled, B., Bopp, L., Bowie, A., Brunet, C., Brussaard, C., Carlotti, F., Christaki, U., Corbière, A., Durand, I., Ebersbach, F., Fuda, J.L., Garcia, N., Gerringa, L., Griffiths, B., Guigue, C., Guillerm, C., Jacquet, S., Jeandel, C., Laan, P., Lefèvre, D., Lomonaco, C., Malits, A., Mosseri, J., Obernosterer, I., Park, Y.-H., Picheral, M., Pondaven, P., Remenyi, T., Sandroni, V., Sarthou, G., Savoye, N., Scouarnec, L., Souhaut, M., Thuiller, D., Timmermans, K., Trull, T., Uitz, J., van-Beek, P., Veldhuis, M., Vincent, D., Viollier, E., Vong, L., and Wagener, T.: Impact of natural iron fertilization on carbon sequestration in the Southern Ocean, Nature, 7139, 1070 1074, 2007.

Blain, S., Sarthou, G., and Laan, P.: Distribution of DFe during the natural iron-fertilization experiment KEOPS, Deep-Sea Res. Pt. II, 55, 594-605, doi:10.1016/j.dsr2.2007.12.028, 2008.

Bowie, A. R., Lannuzel, D., Remenyi, T. A., Wagener, T., Lam, P. J., Boyd, P. W., Guieu, C., Townsend, A. T., and Trull, T. W.: Biogeochemical iron budgets of the Southern Ocean south of Australia: Decoupling of iron and nutrient cycles in the subantarctic zone by the summertime supply, Global Biogeochem. Cy., 23, GB4034, doi:10.1029/2009GB003500, 2009.
Bowie, A. R., van der Merwe, P., Quéroué, F., Trull, T., Fourquez, M., Planchon, F., Sarthou, G., Chever, F., Townsend, A. T., Obernosterer, I., Sallée, J.-B., and Blain, S.: Iron budgets for three distinct biogeochemical sites around the Kerguelen archipelago (Southern Ocean) during the natural fertilisation experiment KEOPS-2, Biogeosciences Discuss., 11, 17861-17923, doi:10.5194/bgd-11-17861-2014, 2014.

Bucciarelli, E., Blain, S., and Tréguer, P.: Iron and manganese in the wake of the Kerguelen Islands (Southern Ocean), Mar. Chem., 73, 21-36, 2001.

Chase, Z., Johnson, K. S., Elrod, V. A., Plant, J. N., Fitzwater, S. E., Pickella, L., and Sakamotob, C. M.: Manganese and iron distributions off central California influenced by upwelling and shelf width, Mar. Chem., 95, 235-254, 2005.

Chever, F., Sarthou, G., Bucciarelli, E., Blain, S., and Bowie, A. R.: An iron budget during the natural iron fertilisation experiment KEOPS (Kerguelen Islands, Southern Ocean), Biogeosciences, 7, 455-468, doi:10.5194/bg-7-455-2010, 2010.

Closset, I., Lasbleiz, M., Leblanc, K., Quéguiner, B., Cavagna, A.J., Elskens, M., Navez, J., and Cardinal, D.: Seasonal evolution of net and regenerated silica production around a natural $\mathrm{Fe}$ fertilized area in the Southern Ocean estimated with $\mathrm{Si}$ isotopic approaches, Biogeosciences, 11, 5827-5846, doi:10.5194/bg-115827-2014, 2014.

Cutter, G., Andersson, P., Codispoti, L., Croot, P., Francois, R., Lohan, M., Obata, H., and Rutgers van der Loeff, M.: Sampling and Sample-handling Protocols for GEOTRACES Cruises, Cookbook, http://www.geotraces.org/ libraries/documents/Intercalibration/Cookbook.pdf (last access: 17 July 2015), 2010.

Cutter, G. A.: Intercalibration in chemical oceanography-Getting the right number, Limnol. Oceanogr.-Meth., 11, 418-424, 2013.

d'Ovidio, F., Della Penna, A., Trull, T. W., Nencioli, F., Pujol, I., Rio, M. H., Park, Y.-H., Cotté, C., Zhou, M., and Blain, S.: The biogeochemical structuring role of horizontal stirring: Lagrangian perspectives on iron delivery downstream of the Kerguelen plateau, Biogeosciences Discuss., 12, 779-814, doi:10.5194/bgd-12-779-2015, 2015.

Doucet, S., Scoates, J. S., Weis, D., and Giret, A.: Constraining the components of the Kerguelen mantle plume: A Hf-Pb-Sr$\mathrm{Nd}$ isotopic study of picrites and high-MgO basalts from the Kerguelen Archipelago, Geochem. Geophy. Geosy., 6, Q04007, doi:10.1029/2004GC000806, 2005.

Dulaiova, H., Ardelan, M. V., Henderson, P. B., and Charette, M. A.: Shelf-derived iron inputs drive biological productivity in the southern Drake Passage, Global Biogeochem. Cy., 23, GB4014, doi:10.1029/2008GB003406, 2009.

Elrod, V. A., Berelson, W. M., Coale, K. H., and Johnson, K. S.: The flux of iron from continental shelf sediments: A missing source for global budgets, Geophys. Res. Lett., 31, L12307, doi:10.1029/2004GL020216, 2004.

Frenot, Y., Van Vliet-Lanoë, B., and Gloaguen, J.-C.: Particle translocation and initial soil development $\mathrm{n}$ a Glacier Foreland, Kerguelen Islands, Subantarctic., Arctic Alpine Res., 27, $107-$ $115,1995$.

Gautier, I., Weis, D., Mennessier, J.-P., Vidal, P., Giret, A., and Loubet, M.: Petrology and geochemistry of the Kerguelen Archipelago basalts (South Indian Ocean) evolution of the man- 
tle sources from ridge to intraplate position, Earth Planet. Sc. Lett., 100, 59-76, 1990.

Hatta, M., Measures, C. I., Selph, K. E., Zhou, M., and Hiscock, W. T.: Iron fluxes from the shelf regions near the South Shetland Islands in the Drake Passage during the austral-winter 2006, Deep-Sea Res. Pt. II, 90, 89-101, 2013.

Hatta, M., Measures, C. I., Wu, J., Roshan, S., Fitzsimmons, J. N., Sedwick, P., and Morton, P.: An overview of dissolved Fe and Mn Distributions during the 2010-2011 U.S. GEOTRACES north Atlantic Cruises: GEOTRACES GA03, Deep-Sea Res. Pt. II, 116, 117-129, doi:10.1016/j.dsr2.2014.07.005, 2015.

Heimburger, A., Losno, R., Triquet, S., and Nguyen, E. B.: Atmospheric deposition fluxes of 26 elements over the Southern Indian Ocean: time series on Kerguelen and Crozet Islands, Global Biogeochem. Cy., 27, 440-449, doi:10.1002/gbc.20043, 2013.

Homoky, W. B., John, S. G., Conway, T. M., and Mills, R. A.: Distinct iron isotopic signatures and supply from marine sediment dissolution, Nature Communications, 4, 2143, doi:10.1038/ncomms3143, 2013.

Ibisanmi, E., Sander, S. G., Boyd, P. W., Bowie, A. R., and Hunter, K. A.: Vertical distributions of iron-(III) complexing ligands in the Southern Ocean, Deep-Sea Res. Pt. II, 58, 2113-2125, 2011.

Jickells, T. D., An, Z. S., Andersen, K. K., Baker, A. R., Bergametti, G., Brooks, N., Cao, J. J., Boyd, P. W., Duce, R. A., Hunter, K. A., Kawahata, H., Kubilay, N., La Roche, J., Liss, P. S., Mahowald, N., Prospero, J. M., Ridgwell, A. J., Tegen, I., and Torres, R.: Global Iron Connections Between Desert Dust, Ocean Biogeochemistry, and Climate, Science, 308, 67-71, 2005.

Johnson, K. S., Chavez, F. P., and Friederich, G. E.: Continental shelf sediments as a primary source of iron to coastal phytoplankton, Nature, 398, 697-700, 1999.

Johnson, K. S., Boyle, E., Bruland, K., Coale, K., Measures, C., Moffett, J., Aguilar-Islas, A., Barbeau, K., Bergquist, B., Bowie, A., Buck, K., Cai, Y., Chase, Z., Cullen, J., Doi, T., Elrod, V., Fitzwater, S., Gordon, M., King, A., Laan, P., Laglera-Baquer, L., Landing, W., Lohan, M., Mendez, J., Milne, A., Obata, H., Ossiander, L., Plant, J., Sarthou, G., Sedwick, P., Smith, G., Sohst, B., Tanner, S., Van den Berg, C. M. G., and Wu, J.: Developping standards for dissolved iron in seawater, EOS Transactions, American Geophysical Union, 88, 131-132, 2007.

Klunder, M. B., Laan, P., De Baar, H. J. W., Middag, R., Neven, I., and Van Ooijen, J.: Dissolved Fe across the Weddell Sea and Drake Passage: impact of DFe on nutrient uptake, Biogeosciences, 11, 651-669, doi:10.5194/bg-11-651-2014, 2014.

Lam, P. J., Bishop, J. K. B., Henning, C. C., Marcus, M. A., Waychunas, G. A., and Fung, I. Y.: Wintertime phytoplankton bloom in the subarctic Pacific supported by continental margin iron, Global Biogeochem. Cy., 20, GB1006, doi:10.1029/2005GB002557, 2006.

Lam, P. J. and Bishop, J. K. B.: The continental margin is a key source of iron to the HNLC North Pacific Ocean, Geophys. Res. Lett., 35, L07608, doi:10.1029/2008GL033294, 2008.

Lasbleiz, M., Leblanc, K., Blain, S., Ras, J., Cornet-Barthaux, V., Hélias Nunige, S., and Quéguiner, B.: Pigments, elemental composition ( $\mathrm{C}, \mathrm{N}, \mathrm{P}$, and $\mathrm{Si}$ ), and stoichiometry of particulate matter in the naturally iron fertilized region of Kerguelen in the Southern Ocean, Biogeosciences, 11, 5931-5955, doi:10.5194/bg-115931-2014, 2014.
Marsay, C. M., Sedwick, P. N., Dinninman, M. S., Barrett, P. M., Mack, S. L., and McGillicuddy Jr., D. J.: Estimating the benthic efflux of dissolved iron on the Ross Sea continental shelf, Geophys. Res. Lett., 41, 7576-7583, doi:10.1002/2014GL061684, 2014.

Martin, J. H., Knauer, G. A., Karl, D. M., and Broenkow, W. W. VERTEX: carbon cycling in the northeast Pacific, Deep-Sea Res. Pt. I, 34, 267-285, 1987.

Measures, C. I., Brown, M. T., Selph, K. E., Apprill, A., Zhou, M., Hatta, M., and Hiscock, W. T.: The influence of shelf processes in delivering dissolved iron to the HNLC waters of the Drake Passage, Antarctica, Deep-Sea Res. Pt. II, 90, 77-88, 2013.

Moore, J. K., Doney, S. C., Glover, D. M., and Fung, I. Y.: Iron cycling and nutrient limitation patterns in surface waters of the World Ocean, Deep-Sea Res. Pt. II, 49, 463-507, 2001.

Morris, P. J. and Charette, M. A.: A synthesis of upper ocean carbon and dissolved iron budgets for Southern Ocean natural iron fertilisation studies, Deep-Sea Res. Pt. II, 90, 147-157, 2013.

Nielsdóttir, M. C., Bibby, T. S., Moore, C. M., Hinz, D. J., Sanders, R., Whitehouse, M., Korb, R., and Achterberg, E. P.: Seasonal and spatial dynamics of iron availability in the Scotia Sea, Mar. Chem., 130-131, 62-72, 2012.

Obata, H., Karatani, H., and Nakayama, E.: Automated determination of iron in seawater by chelating resin concentration and chemiluminescence, Anal. Chem., 65, 1524-1528, 1993.

Park, Y.-H., Durand, I., Kestenare, E., Rougier, G., Zhou, M., d'Ovidio, F., Cotté, C., and Lee, J.-H.: Polar Front around the Kerguelen Islands: An up-to-date determination and associated circulation of surface/subsurface waters, J. Geophys. Res.Oceans, 119, 6575-6592, doi:10.1002/2014JC010061, 2014.

Planquette, H., Sanders, R. R., Statham, P. J., Morris, P. J., and Fones, G. R.: Fluxes of particulate iron from the upper ocean around the Crozet Islands: A naturally iron-fertilized environment in the Southern Ocean, Global Biogeochem. Cy., 25, GB2011, doi:10.1029/2010GB003789, 2011.

Planquette, H. F., Statham, P. J., Fones, G. R., Charette, M. A., Moore, C. M., Salter, I., Nédélec, F. H., Taylor, S. L., French, M., Baker, A. R., Mahowald, N., and Jickells, T. D.: Dissolved iron in the vicinity of the Crozet Islands, Southern Ocean, DeepSea Res. Pt. II, 54, 1999-2019, doi:10.1016/j.dsr2.2007.07.019, 2007.

Pollard, R. T., Salter, I., Sanders, R. J., Lucas, M. I., Moore, C. M., Mills, R. A., Statham, P. J., Allen, J. T., Baker, A. R., Bakker, D. C. E., Charette, M. A., Fielding, S., Fones, G. R., French, M., Hickman, A. E., Holland, R. J., Hughes, J. A., Jickells, T. D., Lampitt, R. S., Morris, P. J., Nédélec, F. H., Nielsdottir, M., Planquette, H., Popova, E. E., Poulton, A. J., Read, J. F., Seeyave, S., Smith, T., Stinchcombe, M., Taylor, S., Thomalla, S., Venables, H. J., Williamson, R., and Zubkov, M. V.: Southern Ocean deep-water carbon export enhanced by natural iron fertilization, Nature, 457, 577-580, doi:10.1038/nature07716, 2009.

Raiswell, R., Vu, H. P., Brinza, L., and Benning, L. G.: The determination of labile $\mathrm{Fe}$ in ferrihydrite by ascorbic acid extraction: methodology, dissolution kinetics and loss of solubility with age and de-watering, Chem. Geol., 278, 70-79, 2010.

Raiswell, R.: Iceberg-hosted nanoparticulate Fe in the Southern Ocean: Mineralogy, origin, dissolution kinetics and source of bioavailable Fe, Deep-Sea Res. Pt. II, 58, 1364-1375, doi:10.1016/j.dsr2.2010.11.011, 2011. 
Sanial, V., van Beek, P., Lansard, B., Souhaut, M., Kestenare, E., d'Ovidio, F., Zhou, M., and Blain, S.: Use of Ra isotopes to deduce rapid transfer of sediment-derived inputs off Kerguelen, Biogeosciences, 12, 1415-1430, doi:10.5194/bg-12-1415-2015, 2015.

Sarthou, G., Baker, A. R., Blain, S., Achterberg, E. P., Boye, M., Bowie, A. R., Croot, P. L., Laan, P., de Baar, H. J. W., Jickells, T. D., and Worsfold, P. J.: Atmospheric iron deposition and sea-surface dissolved iron concentrations in the eastern Atlantic Ocean, Deep-Sea Res. Pt. I, 50, 1339-1352, 2003.

Sarthou, G., Timmermans, K. R., Blain, S., and Tréguer, P.: Growth physiology and fate of diatoms in the ocean: a review, J. Sea Res., 53, 25-42, 2005.

Savoye, N., Trull, T. W., Jacquet, S. H. M., Navez, J., and Dehairs, F.: ${ }^{234}$ Th-based export fluxes during a natural iron fertilization experiment in the Southern Ocean (KEOPS), Deep-Sea Res. Pt. II, 55, 841-855, 2008.

Smith Jr., W. O., Sedwick, P. N., Arrigo, K. R., Ainley, D. G., and Orsi, A. H.: The Ross Sea in a sea of change, Oceanography, 25, 44-57, 2012.

Sunda, W. G. and Huntsman, S. A.: Iron uptake and growth limitation in oceanic and coastal phytoplankton, Mar. Chem., 50, 189-206, 1995.

Sunda, W. G.: Control of dissolved iron concentrations in the world ocean: A comment, Mar. Chem., 57, 169-172, 1997.

Tagliabue, A., Bowie, A., Chever, F., Baptiste, P.-J., Dutay, J.-C., Bucciarelli, E., Lannuzel, D., Remenyi, T., Sarthou, G., Aumont, O., Gehlen, M., and Bopp, L.: On the importance of hydrothermalism to the oceanic dissolved iron inventory, Nat. Geosci., 3, 252-256, doi:10.1038/NGEO818, 2010.
Tagliabue, A., Mtshali, T., Aumont, O., Bowie, A. R., Klunder, M. B., Roychoudhury, A. N., and Swart, S.: A global compilation of dissolved iron measurements: focus on distributions and processes in the Southern Ocean, Biogeosciences, 9, 2333-2349, doi:10.5194/bg-9-2333-2012, 2012.

Thuróczy, C.-E., Gerringa, L. J. A., Klunder, M. B., Laan, P., and de Baar, H. J. W.: Observation of consistent trends in the organic complexation of dissolved iron in the Atlantic Sector of the Southern Ocean, Deep-Sea Res. Pt. II, 58, 2695-2706, 2011.

Twining, B. S., Baines, S. B., and Fisher, N. S.: Element stoichiometries of individual plankton cells collected during the Southern Ocean Iron Experiment (SOFeX), Limnol. Oceanogr., 49, 21152128, 2004.

van der Merwe, P., Bowie, A. R., Quéroué, F., Armand, L., Blain, S., Chever, F., Davies, D., Dehairs, F., Planchon, F., Sarthou, G., Townsend, A. T., and Trull, T. W.: Sourcing the iron in the naturally fertilised bloom around the Kerguelen Plateau: particulate trace metal dynamics, Biogeosciences, 12, 739-755, doi:10.5194/bg-12-739-2015, 2015.

Wagener, T., Guieu, C., Losno, R., Bonnet, S., and Mahowald, N.: Revisiting atmospheric dust export to the Southern Hemisphere ocean: Biogeochemical implications, Global Biogeochem. Cy., 22, GB2006, doi:10.1029/2007GB002984, 2008.

Walsh, I., Fischer, K., Murray, D., and Dymond, J.: Evidence for resuspension of rebound particles from near-bottom sediment traps, Deep-Sea Res. Pt. I, 35, 59-70, 1988. 